\title{
Multiple functions of DOA1 in Candida albicans
}

\author{
Correspondence \\ Bernhard Hube \\ bernard.hube@hki-jena.de
}

Received 22 September 2006

Revised 21 November 2006

Accepted 30 November 2006

\section{Donika Kunze, ${ }^{1}$ Donna MacCallum, ${ }^{2}$ Frank C. Odds ${ }^{2}$ and Bernhard Hube ${ }^{1,3,4}$}

\author{
${ }^{1}$ Robert Koch-Institut, Nordufer 20, D-13353, Berlin, Germany \\ ${ }^{2}$ Aberdeen Fungal Group, School of Medical Sciences, University of Aberdeen, Aberdeen \\ AB25 2ZD, UK \\ ${ }^{3}$ Friedrich-Schiller-University, Jena, Germany \\ ${ }^{4}$ Department of Microbial Pathogenicity Mechanisms, Lelbniz Institute for Natural Product \\ Research and Infection Biology - Hans Knoell Institute Jena (HKI), Beutenbergstraße 11a, \\ D-07745 Jena, Germany
}

\begin{abstract}
While searching for regulators of virulence attributes of the human-pathogenic fungus Candida albicans, a gene was identified similar to the genes encoding the mammalian phospholipase A2activating protein (PLAP) and the Saccharomyces cerevisiae protein Doa1, which is known to play a key role during ubiquitin (Ub)-dependent protein degradation. All three proteins contain WD-repeats. Both PLAP and CaDoa1 contain a mellitin-like sequence with a central 'KVL'. This mellitin-like sequence was shown to be necessary for full function of CaDoa1. CaDOA1 was expressed under all conditions investigated. Gene disruption of $\mathrm{CaDOA} 1$ caused phenotypes including modified colony morphologies, temperature sensitivity, reduced secretion of hydrolytic enzymes and hypersensitivity to various compounds such as propranolol, butanol, caffeine, chelators, azoles, nocodazole and cadmium. Strikingly, mutants lacking $D O A 1$ were filamentous and grew as pseudohyphae and true hyphae under conditions that normally support yeast growth. Transcriptional profiling of $\Delta d o a 1$ indicated that several genes associated with Ub-mediated proteolysis, including CDC48 and UB/4, are upregulated. These data suggest that DOA1 of $C$. albicans, like its orthologue in S. cerevisiae, is associated with Ub-mediated proteolysis and has multiple functions. However, some functions of CaDoa1 seem to be unique for C. albicans. These results support the hypothesis that $\mathrm{Ub}$-mediated proteolysis plays an important role in the regulation of morphology in C. albicans.
\end{abstract}

\section{INTRODUCTION}

The human-pathogenic yeast Candida albicans has become one of the model microbes to investigate the principles of fungal pathogenicity and host-fungus interactions. Since the genome of $C$. albicans has been sequenced and sequence data made available to the scientific community (http:// www-sequence.stanford.edu/group/candida/; http://genolist. pasteur.fr/CandidaDB), significant progress has been made in understanding the biology of this fungus on the basis of comparative and functional genomics (Jones et al., 2004). This includes knowledge about genes and factors associated with virulence attributes of $C$. albicans such as adhesion factors, the ability to alter cell morphology between yeast, pseudohyphal and hyphal forms, and the secretion of hydrolases (Calderone \& Fonzi, 2001). For the latter, gene

Abbreviations: DAG, diacylglycerol; LPC, lysophosphatidylcholine; PA, phosphatidic acid; PC, phosphatidylcholine; PLAP, phospholipase A2activating protein; Ub, ubiquitin.

The GEO accession number for the data reported in this paper is GSE 6905. families have been discovered which encode secreted proteinases (Naglik et al., 2003), lipases (Hube et al., 2000) and phospholipases (Ghannoum, 2000). Genes encoding phospholipases B, C and D have been described and their impact on pathogenesis of C. albicans infections studied (Ghannoum, 2000; Hube et al., 2001; Knechtle et al., 2005; Kunze et al., 2005). However, although earlier reports demonstrated extracellular phospholipase A activity (Goyal \& Khuller, 1992; Takahashi et al., 1991), no gene encoding a putative secretory phospholipase A has so far been identified.

With the increasing information gained about single virulence attributes and fitness factors, research has moved on to those factors which regulate the molecular and cellular processes associated with pathogenicity. One of the best examples of regulatory networks linked to processes essential for virulence of $C$. albicans is the regulation of morphogenesis (Kumamoto \& Vinces, 2005a). Here, two major pathways, a MAP-kinase and a cAMP pathway, are of central importance for the initiation of hypha formation, but several other factors have also been identified to be crucial for hyphal morphogenesis. In particular, the key 
transcriptional factor of the cAMP pathway, Efg1, was shown to be essential not only for hypha formation under most conditions (Lo et al., 1997; Stoldt et al., 1997), but also for the expression of virulence attributes associated with dimorphism, such as the adhesion molecule Hwp1 or the secreted aspartic proteinases Sap4-6 (Felk et al., 2002; Kumamoto \& Vinces, 2005b; Sundstrom, 2002).

Regulation of cellular processes in fungi has been studied extensively in the yeast Saccharomyces cerevisiae. In principle, regulation of eukaryotic cells occurs on a number of different levels including genomic, transcriptional and post-transcriptional (Castrillo \& Oliver, 2006). One of the central post-translational mechanisms of regulation in eukaryotic cells is the controlled proteolysis of proteins such as transcription factors via ubiquitination. Protein ubiquitination is catalysed by ubiquitin (Ub) ligases in concert with Ub-conjugating enzymes, which facilitate the formation of an isopeptide bond between the Cterminus of $\mathrm{Ub}$ and a lysine side chain of a target protein (Sung et al., 1988). The specific biological signal mediated by a polyubiquitin chain is determined, in part, by chain topology, which is differentiated by the Ub lysine residue used for chain extension (Hofmann \& Pickart, 2001; Pickart, 1997). Escort factors are involved in targeting ubiquitinated substrates to the proteosome (Rumpf \& Jentsch, 2006). Furthermore, protein ubiquitination is reversible as $\mathrm{Ub}$ can be removed by deubiquitinating enzymes (Amerik et al., 2000). These regulatory processes require a network of factors to ensure a timely, precise and specific degradation of proteins with distinct cellular functions. In S. cerevisiae, it has been shown that one of the proteins associated with the escort factor Cdc48 is Doal, which acts as an adaptor that possesses a novel Ub binding domain (Mullally et al., 2006).

While searching for regulators which may be involved in phospholipase A activation in C. albicans, we identified a gene homologous to the mammalian PLAP (phospholipase A2-activating protein) (Clark et al., 1991) and the $S$. cerevisiae protein Doal (Ghislain et al., 1996; Hochstrasser \& Varshavsky, 1990; Johnson et al., 1995; Mullally et al., 2006). The orthologue of Doal is involved in multiple cellular processes in C. albicans, including filamentous growth, diacylglycerol production, cell wall integrity, mitotic spindle formation, heavy metal tolerance, growth on non-fermentable carbon sources and haemolytic activity.

\section{METHODS}

Strains and growth conditions. In this study we used C. albicans strains SC5314 and CAF2-1 as wild-type controls and CAI-4 to produce mutants either lacking or overexpressing CaDOA1 (Fonzi \& Irwin, 1993). Cells were grown in YPD $[2 \%(\mathrm{w} / \mathrm{v})$ glucose, $1 \%$ $(\mathrm{w} / \mathrm{v})$ yeast extract, $2 \%(\mathrm{w} / \mathrm{v})$ bacto peptone] or SD $[2 \%(\mathrm{w} / \mathrm{v}) \mathrm{glu}-$ cose, $0.5 \%(\mathrm{w} / \mathrm{v})\left(\mathrm{NH}_{4}\right)_{2} \mathrm{SO}_{4}, 0.17 \%(\mathrm{w} / \mathrm{v})$ yeast nitrogen base without amino acids and ammonium sulphate; Difco]. For phenotype screening and expression studies the following media were used: M199 (Sigma), CAA medium (Leuker et al., 1997; Stoldt et al., 1997), Sabouraud glucose medium $[2 \%(\mathrm{w} / \mathrm{v})$ glucose, $1 \%(\mathrm{w} / \mathrm{v})$ bacto peptone], YCB-BSA (Hube et al., 1994), blood agar $\{11$ bouillon
[0.3\% (w/v) NaCl, $0.3 \%(w / v) \mathrm{Na}_{2} \mathrm{HPO}_{4} \cdot 2 \mathrm{H}_{2} \mathrm{O}, 1 \%$ (w/v) bacto peptone, $1.4 \%(\mathrm{w} / \mathrm{v})$ Lab-Lemco powder (Oxoid)], $15 \mathrm{~g}$ agar, $50 \mathrm{ml}$ mutton blood\}, Lee's medium pH 4.5 and 6.5 (Buffo et al., 1984), egg

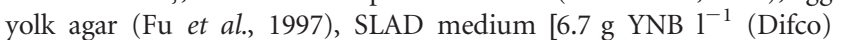
without amino acids and ammonium sulphate plus $0.05 \mathrm{mM}$ $\left.\left(\mathrm{NH}_{4}\right)_{2} \mathrm{SO}_{4}\right]$, Spider agar (Liu et al., 1994), YPD plus $5 \%(\mathrm{v} / \mathrm{v})$ fetal calf serum (FCS) (YSer) or SD containing cadmium sulphate, propranolol, butanol, caffeine, EDTA, $\mathrm{LiCl}, \mathrm{MnCl}_{2}, \mathrm{ZnCl}_{2}, \mathrm{CuCl}_{2}, \mathrm{NaCl}$, $\mathrm{H}_{2} \mathrm{O}_{2}$, hygromycin $\mathrm{B}$, cycloheximide, tetracycline, benomyl, Congo Red, SDS, amphotericin B, amorolfine, cyclosporin A, calcofluor, ciclopirox, isoflurane, nocodazole or itraconazole at appropriate concentrations.

For phenotypic screening of mutant strains a serial drop dilution test was used. Five microlitre suspensions of tenfold dilutions of cells were dropped onto the corresponding solid media.

For expression analysis, CAF2-1 was grown overnight at $30^{\circ} \mathrm{C}$ in $\mathrm{SD}$ medium, diluted into fresh SD medium to give a concentration of $10^{6}$ cells $\mathrm{ml}^{-1}$ and incubated at $37^{\circ} \mathrm{C}$ to an $\mathrm{OD}_{600}$ of 0.6 . The culture was then divided into $40 \mathrm{ml}$ aliquots, centrifuged and the pellet resuspended in $40 \mathrm{ml}$ of one of the media described above. After a given incubation period, cells were harvested for RNA extraction (see below). For induction of the PCK1 promoter we used media without glucose: SGlyc [SD with $2 \%(\mathrm{v} / \mathrm{v})$ glycerol instead of glucose] or SGlycAc [SD with $3 \%(\mathrm{v} / \mathrm{v})$ glycerol and $2 \%(\mathrm{w} / \mathrm{v})$ potassium acetate instead of glucose], CAA medium and succinate medium (B medium) (Leuker et al., 1997; Stoldt et al., 1997).

For cloning procedures, E. coli TOP10 cells (Invitrogen) were used as described by the manufacturer.

Microscopic investigations. For viability staining, we used the LIVE/DEAD Yeast Viability Kit (Molecular Probes), according to the manufacturer's instructions. Briefly, $50 \mu \mathrm{l}$ cells from a culture in late exponential phase were mixed with $1 \mathrm{ml}$ sterile medium. Cells were harvested and resuspended in fresh medium at a cell density of $10^{6}-10^{7}$ cells $\mathrm{ml}^{-1}$. The sample was mixed with the stain FUN1 (final concn $20 \mu \mathrm{M}$ ) and incubated for $30 \mathrm{~min}$ at $30^{\circ} \mathrm{C}$ in the dark. Calcofluor white was used to stain fungal chitin and to discriminate between true hyphal cells and pseudohyphae. Stained cells were analysed with a fluorescence microscope.

Disruption of DOA1. To disrupt DOA1 we produced the following plasmids. Primers DOA1-3 fwd, containing a SalI restriction site, and DOA1-4 rev with genomic DNA from strain SC5314 were used to amplify a $433 \mathrm{bp}$ fragment from the $3^{\prime}$ end of $D O A 1$ (all primers are summarized in Table 1). The PCR product was cloned into pCR2.1-TOPO to give pDK-9. The DOA1 insert was released with HindIII and SalI and ligated into those sites of vector pMB7 to give pDK-10. Primers DOA1-1b fwd and DOA1-2a rev were used to amplify a $745 \mathrm{bp}$ fragment of the $5^{\prime}$ end of DOA1 and the PCR product was cloned into pCR2.1-TOPO to give pDK-11. Next, a HindIII and KpnI fragment of pDK-10 containing the $3^{\prime}$ end of DOA1 and the hisG-URA-hisG cassette was ligated into pDK-11 digested with the same enzymes to give the final disruption cassette, pDK-12. The disruption cassette was used to transform C. albicans CAI-4 as described below. Integration of the disruption cassette at the correct locus, disruption of DOA1 and the genotypes of all other mutants, revertants and overexpressing strains described below were confirmed by PCR and Southern blot analysis. All strains produced in this study are summarized in Table 2 .

Construction of a conditional DOA1 mutant. To produce a conditional DOA1 mutant we used primers DOA1-UE1 and DOA1UE2, containing BglII sites, to amplify the entire DOA1 gene, including $200 \mathrm{bp}$ of the $3^{\prime}$ end, using the Long Expand Kit (Roche). The PCR fragment was subcloned into pGEM-T Easy (Promega) to give 
Table 1. Primers used in this study

\begin{tabular}{|llc|}
\hline Primer & Gene & \multicolumn{1}{c|}{ Sequence $\left(\mathbf{5}^{\prime} \mathbf{-} \mathbf{3}^{\prime} \mathbf{)}\right.$} \\
\hline DOA1-3 fwd & DOA1 & GTC GAC CGA GCC ACC ATT GAA \\
DOA1-4 rev & DOA1 & GT GAT TAA TTC TAG CGC TTG C \\
DOA1-1b fwd & DOA1 & ATC GGC ACT ACA AGT TAA ATA GTG \\
DOA1-2a rev & DOA1 & AGA TCT ATG TCT TAC AAA CTT AGT \\
DOA1-UE1 fwd & DOA1 & AGA TCT ATT AGA GAT TCA TAA GAA \\
DOA1-UE2 rev & DOA1 & GGT ACC GGC ACT GAC AAT AAA TTA TA \\
DOA1-k1a-fwd & DOA1 & GGT ACC AAG TGC TGG ATT TTC CAC AT \\
DOA1-k1a-rev & DOA1 & ACC GAA GCT CCA ATG AAT CCA \\
ACT1 fwd & ACT1 & GGA TGG ACC AGA TTC GTC GTA \\
ACT1 rev & ACT1 & AGT CAT TGA ACG AAT TCT TGG CTG \\
EFB1 fwd & EFB1 & TTC TTC AAC AGC AGC TTG TAA GTC \\
EFB1 rev & EFB1 & \\
\hline
\end{tabular}

pDK-21. The fragment was released with BglII and ligated into pBI1 (Stoldt et al., 1997) fusing the $5^{\prime}$ end to the PCK promoter (pDK22). The plasmid was used to transform $\Delta$ doal and CAI-4.

Construction of a DOA1 mutant lacking the mellitin domain. We amplified the DOAl gene lacking an internal $75 \mathrm{bp}$ fragment (containing the KVL-site) by inverse PCR (Long Expand Kit; Roche) by use of plasmid pDK-21 as a template and primers DOAl-kla fwd and rev, containing KpnI sites. The linear fragment was digested with $K p n \mathrm{I}$ and religated to give pDK-26. The insert of pDK-26 was released with BglII and ligated into pBI- 1 at the BglII site to give pDK-27. The plasmid was used to transform $\Delta$ doa1.

Transformation of C. albicans. To transform C. albicans, two modified lithium acetate protocols (Sanglard et al., 1997) and one electroporation protocol (De Backer et al., 1999) were used. Transformants were screened by PCR and Southern blot analysis as described previously (Felk et al., 2002).
RNA extraction and RT-PCR. Liquid cultures were grown as described for each experiment, and cells were harvested and RNA isolated as described previously (Felk et al., 2002). For RT-PCR, $1.5 \mu \mathrm{g}$ RNA was DNase-treated and cDNA was synthesized (Felk et al., 2002). Controls included cDNA synthesis without addition of reverse transcriptase and amplification of an intron-containing fragment of the EFB1 gene (Schaller et al., 1999) (with primers EFB1 fwd and EFB1 rev in Table 1). To ensure that samples from the exponential phase of PCR amplification were examined, we used 20, 25, 30, 35 and 40 (or more) cycles. All RT-PCR experiments were done at least in duplicate with samples from two independent biological experiments. An additional internal standard control was the housekeeping gene ACT1, amplified with primers ACT1 fwd and ACT1 rev.

Microarray hybridization and analysis. For transcript profiling, we used C. albicans microarrays (Eurogentec) containing 6039 ORFs. Arrays were designed as described at www.galarfungail.org/

Table 2. Strains used in this study

\begin{tabular}{|c|c|c|c|}
\hline Strain no. & Strain & Genotype & Source or reference \\
\hline & SC5314 & Wild-type strain & $\begin{array}{l}\text { Clinical isolate, } \\
\text { Gillum et al. (1984) }\end{array}$ \\
\hline & CAF2-1 & SC5314 derivative $\Delta$ ura $3:: i m m 434 / U R A 3$ & Fonzi \& Irwin (1993) \\
\hline & CAI4 & SC5314 derivative $\Delta u r a 3::$ imm434/Dura3: : imm434 & Fonzi \& Irwin (1993) \\
\hline DK1 & $\Delta$ doal/DOA1 & CAI4 derivative, $\triangle$ doal: : hisG-URA3-hisG/DOA1 & This study \\
\hline DK1-1 & $\triangle d o a 1 / D O A 1$ & CAI4 derivative, $\triangle$ doal $:$ his $G / D O A 1$ & This study \\
\hline DK2 & $\Delta$ doal/ $\Delta$ doal & CAI4 derivative, $\Delta$ doal : : his G/ $\Delta$ doal: : hisG-URA3-hisG & This study \\
\hline DK2-1 & $\Delta$ doal/ $\Delta$ doa 1 & CAI4 derivative, $\Delta$ doal $::$ his $G / \Delta$ doal $::$ his $G$ & This study \\
\hline DK3 & $\Delta$ doal $/ \Delta$ doa $1+\mathrm{pBI}-1-D O A 1$ & $\begin{array}{l}\text { CAI4 derivative, } \Delta \text { doal }: \text { his } G / \Delta \text { doal }: \text { : his } G \text { carrying } \\
\text { pBI-1-DOA1 }\end{array}$ & This study \\
\hline DK4 & $\mathrm{CAI} 4+\mathrm{pBI}-1-D O A 1$ & CAI4 carrying pBI-1-DOA1 & This study \\
\hline DK5 & $\Delta d o a 1 / \Delta d o a 1+\mathrm{pBI}-1$ & $\begin{array}{l}\text { CAI4 derivative, } \Delta \text { doal }: \text { : his } G / \Delta \text { doal }: \text { : his } G \text { carrying } \\
\text { empty pBI-1 }\end{array}$ & This study \\
\hline DK6 & $\Delta d o a 1 / \Delta d o a 1+\mathrm{pBI}-1-D O A 1-\mathrm{KVL}$ & $\begin{array}{l}\text { CAI4 derivative, } \Delta \text { doal }: \text { : his } G / \Delta \text { doal }: \text { : his } G \text { carrying } \\
\text { pBI-1- } \triangle D O A 1\end{array}$ & This study \\
\hline DK7 & $\Delta d o a 1 / \Delta d o a 1+$ CIp 10 & $\begin{array}{l}\text { CAI4 derivative, } \Delta \text { doal: : hisG/ } \Delta \text { doal }: \text { : hisG rps1:: } \\
\text { CIp10/RPS1 }\end{array}$ & This study \\
\hline DK8 & $\Delta d o a 1 / \Delta d o a 1+$ CIp10-DOA1 & $\begin{array}{l}\text { CAI4 derivative, } \Delta \text { doal }:: \text { hisG/ } \Delta \text { doal:: hisG, rps1:: } \\
\text { CIp10-DOA1/RPS1 }\end{array}$ & This study \\
\hline
\end{tabular}


data.htm. Information about coding sequences and proteins was obtained from the CandidaDB database (http://genolist.pasteur.fr/ CandidaDB/). RNA was reverse-transcribed into cDNA and labelled with Cy3 or Cy5 (dye swap) (Sigle et al., 2005). Labelled cDNA was hybridized to the C. albicans arrays as described by Sigle et al. (2005). For each experiment, triplicate arrays were used: two biological replicates and one dye swap. Hybridized slides were scanned with an Axon 4000B scanner at $10 \mu \mathrm{m}$ resolution. Data were extracted using GenePix 4.1 software (Axon). An intensitydependent data normalization (LOWESS) was performed using GeneSpring 6.0. The different sets of data were compared to each other by one-way analysis of variance (ANOVA) test with a $P$ value cut-off of $<0.05$ for genes that had an intensity in both channels higher than 100. Each gene that passed this test and showed at least 1.4-fold change in two arrays was defined as differentially expressed.

Systemic mouse infection. C. albicans strains ( $\Delta$ doal/Ddoal, CAF2-1) were used in a mouse model of systemic infection as described previously (Fradin et al., 2005).

Phospholipase assay. To estimate phospholipase A-like activity in culture supernatants and soluble cell fractions, we used the NEFA $\mathrm{C}$ kit (WAKO) which measures free fatty acids after addition of lysophosphatidylcholine (LPC) and phosphatidylcholine (PC) as substrates. Samples were incubated at $\mathrm{pH} 6.0$ and 7.5 with and without the addition of calcium ions. C. albicans cells were cultured in SD medium at $30^{\circ} \mathrm{C}$ and used to inoculate Lee's medium ( $\mathrm{pH} \mathrm{4.5)}$ at $25^{\circ} \mathrm{C}$. Selected media were inoculated with cells from this preculture at a density of $10^{6}$ cells $\mathrm{ml}^{-1}$ and incubated for $15 \mathrm{~h}$. One millilitre samples were taken for morphological analysis and to measure phospholipase activity. For the latter, samples were centrifuged for $5 \mathrm{~min}$ at $14300 \mathrm{~g}$ and $800 \mu \mathrm{l}$ of the supernatant was used to measure the extracellular phospholipase activity. The cells in the pellet were resuspended in $1 \mathrm{ml}$ Tris/ $\mathrm{HCl}(40 \mathrm{mM}, \mathrm{pH} 7.5)$ and lysed with glass beads $(40 \mathrm{~min})$. Cell debris was removed by centrifugation and soluble proteins were used to measure intracellular phospholipase activity. Phospholipase activity was measured according to the manufacturer's instructions with appropriate controls (e.g. medium only). Fatty acid concentrations were measured according to a standard curve based on 0.0, 0.2, 0.4 and $1.0 \mathrm{mM}$ oleic acid. All samples were analysed in duplicates. Protein concentrations were measured with the Biuret-based BCA Protein Assay Reagent Kit (Pierce).

\section{RESULTS}

\section{Sequence analysis of IPF4477 (CaDOA1)}

One of our aims in this study was to identify putative virulence genes and regulators of virulence in C. albicans. Since phospholipase A activity has been reported as a putative virulence factor of C. albicans (Goyal \& Khuller, 1992; Takahashi et al., 1991), we have searched in one of the C. albicans genome databases (http://genolist.pasteur.fr/ CandidaDB/) for putative phospholipase A genes. While no gene with significant similarity to phospholipase A genes was found, we identified a gene similar to the human gene encoding PLAP, known to be associated with the regulation of phospholipase A (Clark et al., 1991). This gene, IPF4477, is identical to CA4750 and orf19.4829 of assembly 19 (http:// www-sequence.Stanford.edu/group/candida; http://genolist. pasteur.fr/CandidaDB/). CA4750 is a $2268 \mathrm{bp}$ gene encoding a cytosolic protein (TargetP V1.0) (Emanuelsson et al., 2000) with 762 a. Using the deduced protein sequence of CA4750 for a BLAST search at NCBI, we identified not only the gene encoding PLAP from mammals such as mice (GI 2507097/P 27612) and rats (GI 2007098/P 54319) (29\% identity), but also Doal (Zzz4, Ufd3) of S. cerevisiae with $35.5 \%$ identity. Based on these results we renamed CA4750 as CaDOA1.

\section{WD repeats}

The most significant similarities between ScDoal and PLAP are based on WD repeats within these proteins. WD repeats are repetitive amino acid sequences with conserved positions for the amino acids GH (Gly-His) and WD (Trp-Asp). The consensus sequence for these domains is $\left(\mathrm{X}_{6-94}-\left[\mathrm{GH}-\mathrm{X}_{23-41}-\mathrm{WD}\right]\right)^{\mathrm{N} 4-8}$, according to Neer et al. (1994), with X describing the variable regions. In PLAP, four such WD repeats are found after a short $\mathrm{N}$-terminal domain and are followed by a long C-terminal stretch (Fig. 1). Using the motif search function of InterPro (Falquet et al., 2002), seven WD repeats were identified in CaDoal. These repeats were found directly at the $\mathrm{N}$ terminus and distributed over the first third of the protein (positions 3-40, 49-84, 87-123, 127-164, 166-204, 208-245 and 249-286).

\section{Mellitin-like sequences}

A mellitin-like sequence at the C-terminus is essential for the phospholipase $\mathrm{A}_{2}$ activation of PLAP (Clark et al., 1991). Comparing mellitin sequences with the mellitin-like sequence of PLAP found by Clark et al. (1991), we identified a conserved motif 'KVL' in CaDoal (Fig. 1).

(a)

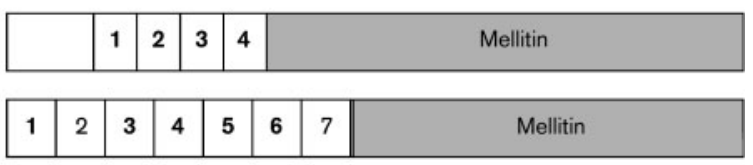

(b)

Mellitin
PLAP mouse
CaDoal
ScDoal
133 GIGAVLKVLT . . TGLPALISWIKRKRQQ . . . . ESPLIAKVLT. .T.EPPIITPVRR. . . . . . . LMMILKVLNNLVGT T LEVQLYIDPC . . . . . . KTSVMKVLP . VKQY LIMEN YNPDTIFNGIVK

Fig. 1. (a) Schematic structure of the mammalian protein PLAP and of CaDoa1. PLAP consists of a short N-terminal sequence followed by four WD repeats and a mellitin-like sequence at the $\mathrm{C}$ terminus (Peitsch et al., 1993). CaDOA1 consists of seven WD repeats starting at the $\mathrm{N}$ terminus and a $\mathrm{C}$-terminal mellitin-like sequence. WD repeats 2 and 7 show low similarities to the consensus sequence. (b) Alignment of mellitin (Clark et al., 1991) with mellitin-like sequences of PLAP (Clark et al., 1991) and Doa1 from C. albicans (CaDoa1). The KVL motif is underlined. Amino acids conserved in at least two of these sequences are marked in bold and italic type. All amino acids shown for CaDoa1 were removed in the deletion mutant lacking the mellitin-like sequence. 


\section{CaDOA1 is expressed in yeast and hyphal cells}

To analyse under which conditions $C a D O A 1$ is expressed in vitro, we used semiquantitative RT-PCR. We analysed the expression of DOA1 in media supporting the yeast growth form and media which induced hypha formation. Yeast cells from a preculture (Lee's medium, $\mathrm{pH} 4.5$, at $25^{\circ} \mathrm{C}$, or SD medium) were used to inoculate media supporting either yeast or hyphal growth with samples taken at several time points (Fig. 2). After $3 \mathrm{~h}$, up to $99 \%$ of all cells had produced germ tubes in the hypha-inducing media (Fig. 2). Using either ACT1 or EFB1 as internal controls and several rounds of PCR to ensure that samples from the exponential phase of PCR amplification were examined, we detected $D O A 1$ transcripts in all samples showing that this gene is constitutively expressed in yeast and hyphal cells under the conditions investigated. However, an increased expression of DOA1 was observed at late stages of yeast growth (Fig. 2).

\section{Gene disruption of DOA1}

To analyse the function of DOA1, we produced mutants lacking this gene with the Ura-blaster protocol (Fonzi \& Irwin, 1993). A disruption cassette was constructed which contained a $745 \mathrm{bp}$ fragment corresponding to position
-274 to +471 bp relative to the ATG start codon of DOA1 and a $433 \mathrm{bp}$ fragment corresponding to position +1181 to +1614 bp relative to the ATG flanking the hisG-URA3-hisG cassette. The disruption cassette was used to disrupt both alleles of DOA1. Integration into both alleles was confirmed by Southern analysis and PCR. Several independent isogenic mutants were produced to verify that no further mutational events occurred during the transformation steps and the 5 -fluoro-orotic acid treatments. For all experiments with the $\Delta$ doa1 mutant (DK2; $\mathrm{Ura}^{+}$) we used the wild-type strains SC5314 and/or CAF2-1 (one copy of URA3) as reference strains.

\section{Mutants lacking DOA1 are filamentous and show reduced growth under multiple conditions}

Mutants lacking DOA1 were analysed under a series of conditions. To analyse growth in liquid media, $\Delta$ doa 1 mutant (DK2) and wild-type cells $\left(10^{6}\right.$ cells $\left.\mathrm{ml}^{-1}\right)$ from an SD preculture at $30^{\circ} \mathrm{C}$, which consisted predominantly of yeast cells, were inoculated into either SD or YPD medium at $37^{\circ} \mathrm{C}$. Microscopic investigation of cells grown under these conditions showed that wild-type cells grew in the yeast form, while $\Delta$ doa 1 mutant cells produced filaments (Fig. 3). By $4 \mathrm{~h}, 98 \%$ of all wild-type cells grew as yeast forms in SD

(a)

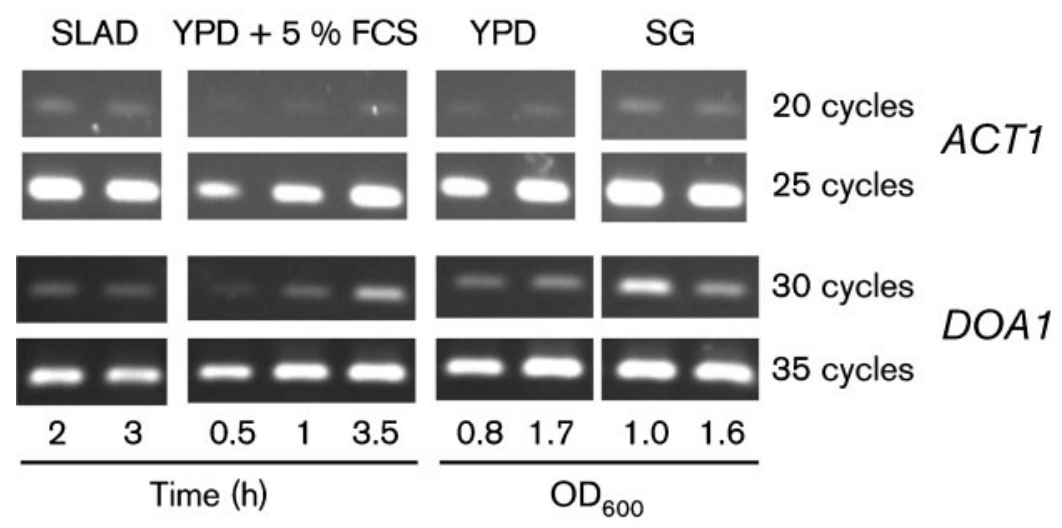

(b)

$\mathrm{pH} 4.5$ (yeast)
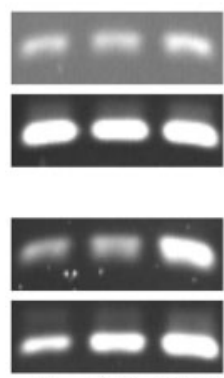

$\begin{array}{lll}7 & 10 & 13.5\end{array}$

$\begin{array}{lll}0.5 & 1.0 & 1.7\end{array}$

$-\quad-$

pH 6.5 (hyphae)

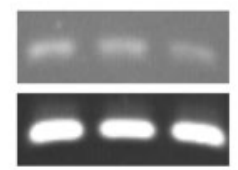

20 cycles

55 cycles

EFB1

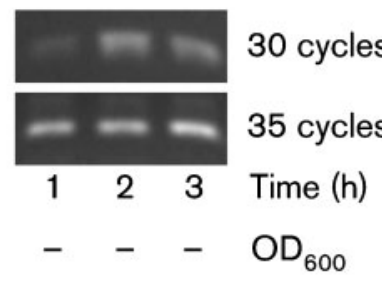

$328699 \%$ hyphae

\section{DOA1}

Fig. 2. Expression of $D O A 1$ during yeast and hyphal growth using semiquantitative RT-PCR. SC5314 was grown in (a) SLAD, YPD plus serum, YPD or SG (Sabouraud glucose), or (b) Lee's medium at either $\mathrm{pH} 4.5$ or 6.5. RNA samples from different time points were used for RT-PCR analysis. Transcripts were amplified with 20-55 cycles using primer pairs that detect $C a D O A 1, A C T 1$ or EFB1. DOA1 is expressed under all conditions and only upregulated at late time points in Lee's medium supporting yeast growth. 
wt
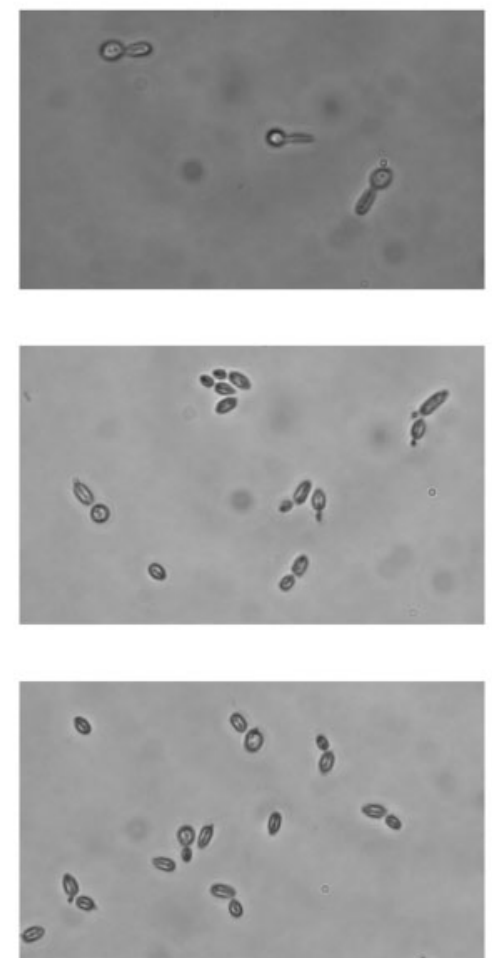

$\Delta$ doa1
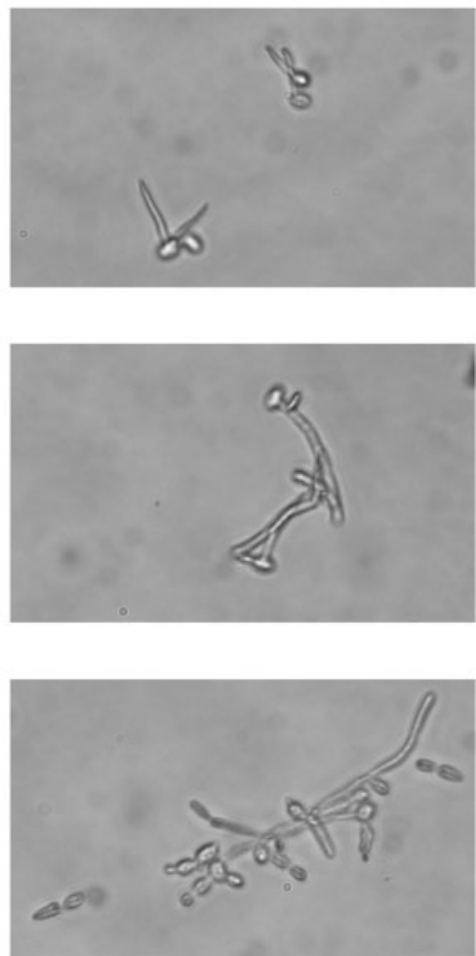

Fig. 3. Filamentous growth of $\Delta$ doa 1 mutant and wild-type (CAF2-1) cells in liquid SD medium incubated at $37^{\circ} \mathrm{C}$ for 2,4 or $6 \mathrm{~h}$. medium (96\% in YPD), while $92 \%$ of $\Delta$ doal cells had formed filaments (YPD, 48\%). Detailed microscopy, including staining with calcofluor white, showed that the filaments produced by the $\Delta$ doal mutant were a mixture of pseudohyphae and true hyphae (Fig. 3).

For analysis on solid media, we used a drop dilution test. For each medium we used two independently produced isogenic $\Delta$ doal mutants, a heterozygote $\Delta$ doal mutant (DK1, one copy of URA3 and DOA1) and the wild-type strain CAF2-1 (one copy of URA3).

The most striking phenotype on solid media was filamentous growth as already shown under liquid conditions. Colonies of $\Delta$ doal mutants grew mostly as filaments in media which normally do not induce hypha formation (Fig. 4). The hyperfilamentous phenotype was often associated with a crumpled colony surface. This includes colonies for which macroscopic production of filaments was not obvious. For example, wild-type growth on YPD at 30 or $37^{\circ} \mathrm{C}$ appeared as smooth, creamy colonies and contained few hyphae, but $\Delta$ doa 1 colonies had a crumpled surface with filamentous cells which could be detached from the agar surface as a firm mass (Fig. 4c). As shown in Fig. 4(c), cells from CAF2-1 colonies consisted of yeast cells only, while cells from the mutant colonies were associated with each other as a network of mainly filaments and few yeast cells. Under conditions which induce hypha formation in wildtype cells (e.g. serum or spider medium), the mutant formed filaments more rapidly and mostly longer than in the wildtype. Growth at 25 and $40{ }^{\circ} \mathrm{C}$ under the same conditions did not alter these phenotypes.
In addition to the morphological differences, we observed a hypersensitivity of the $\Delta$ doal mutants to several compounds (Fig. 4). For example, the addition of propranolol strongly reduced growth of the $\Delta d o a 1$ mutants. This compound is known to inhibit the lipid phosphate phosphohydrolases that convert phosphatidic acid (PA) into diacylglycerol (DAG) and hence hypha formation in C. albicans (Baker et al., 2002). Furthermore, the metabolic inhibitor caffeine and the chelator EDTA caused severe growth inhibition of $\Delta$ doal mutants. The inhibition caused by EDTA (more pronounced at $30^{\circ} \mathrm{C}$ ) was reversible by addition of either $\mathrm{MnCl}_{2}(15 \mathrm{mM}), \mathrm{ZnCl}_{2}(25,50 \mu \mathrm{M})$ or $\mathrm{CuCl}_{2}$ (50, $100 \mu \mathrm{M}$ ), with $\mathrm{MnCl}_{2}$ being the most efficient and $\mathrm{CuCl}_{2}$ the least efficient salt for reversing the effect (not shown). An increased susceptibility was also observed with antifungal agents such as itraconazole. Similar results were obtained with nocodazole, which causes disassembly of mitotic spindles. Since it had been shown that $S$. cerevisiae mutants lacking DOA1 were sensitive to volatile anaesthetic agents such as isoflurane (Keil et al., 1996), we also investigated the isoflurane sensitivity of the $\Delta$ doa 1 mutants from $C$. albicans and found they grew slower as compared to wild-type cells. The observed phenotypes varied with the temperature of incubation. For example, higher concentrations of $\mathrm{CdSO}_{4}$ $(120 \mu \mathrm{M})$ or butanol $(4 \%)$ were necessary at $30{ }^{\circ} \mathrm{C}$ compared with $30 \mu \mathrm{M} \mathrm{CdSO}$ or $2 \%$ butanol at $37^{\circ} \mathrm{C}$ to cause growth inhibition of the $\Delta$ doa 1 mutants (not shown). Use of non-fermentable carbon sources such as glycerol or acetate instead of glucose led to reduced growth of the $\Delta$ doal mutant at $37^{\circ} \mathrm{C}$, but not at $30^{\circ} \mathrm{C}$ (not shown). To investigate the haemolytic activity of $\Delta$ doa 1 mutants, we also inoculated 
(a)

$\mathrm{SD}, 37^{\circ} \mathrm{C}, 3$ days

$\mathrm{SD}, 30^{\circ} \mathrm{C}, 3$ days

Spider, $37^{\circ} \mathrm{C}, 3$ days

$\mathrm{M} 199,37^{\circ} \mathrm{C}, 3$ days $37^{\circ} \mathrm{C}, 6$ days

FCS $5 \%$,

$37^{\circ} \mathrm{C}, 6$ days

Caffeine $10 \mathrm{mM}$, $37^{\circ} \mathrm{C}, 5$ days, SD

$\mathrm{CdSO}_{4} 15 \mu \mathrm{M}, 37^{\circ} \mathrm{C}$,

3 days, SD

EDTA $1 \mathrm{mM}, 30^{\circ} \mathrm{C}$, 3 days, SD

$\mathrm{EDTA}+\mathrm{MnCl}_{2}$ $15 \mathrm{mM}, 30^{\circ} \mathrm{C}, 3$ days

Isofluran $100 \mu \mathrm{l}, 30^{\circ} \mathrm{C}$, 2 days, SD

SGlycAc, $37^{\circ} \mathrm{C}, 6$ days

Nocodazole $4 \mathrm{\mu g} \mathrm{ml}^{-1}$, $37^{\circ} \mathrm{C}, 5$ days, SD

Itraconazole $1 \mu \mathrm{g} \mathrm{ml}^{-1}$, $37^{\circ} \mathrm{C}, 5$ days, SD wt
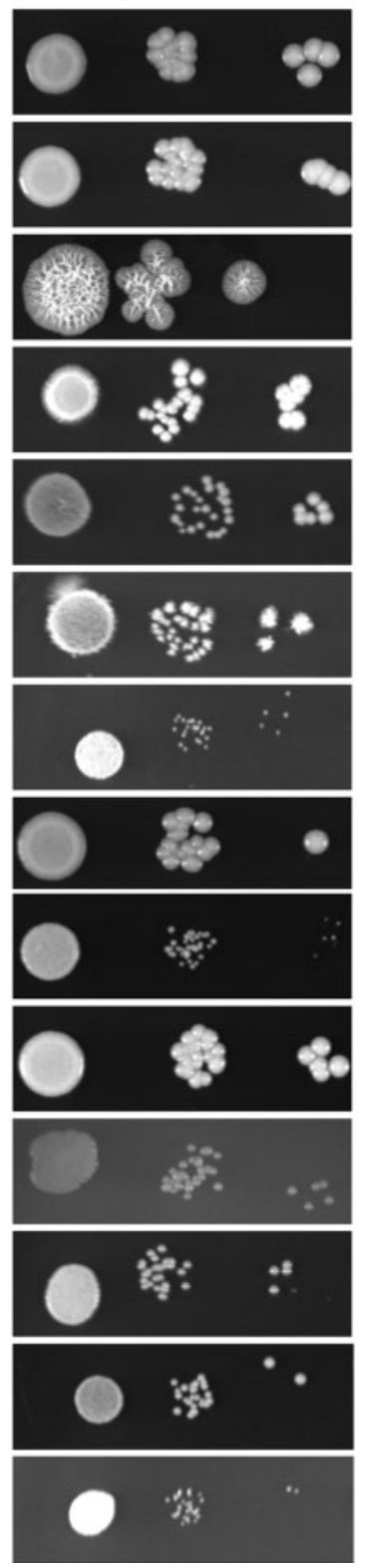

$\Delta$ doa1
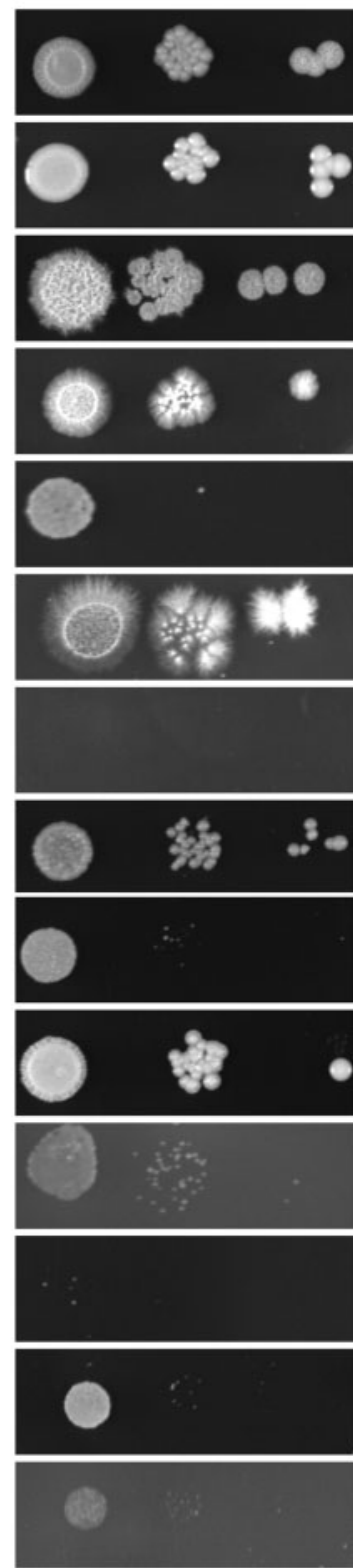

Fig. 4. Colony and cellular morphology of sdoa1. (a) Wild-type (wt) (CAF2-1) and mutant cells were dropped at concentrations of $5 \times 10^{3}, 5 \times 10^{1}$ or 5 cells per $5 \mu$ onto agar plates and incubated under the given conditions. (b) Morphology of wild-type and mutant colonies on protein agar (YCB/BSA) and blood agar. (C) Colony and cellular morphology of $\Delta$ doa1 as compared to the wildtype. Cells were scratched from the colony surface, diluted in water and investigated under the microscope. Mutant cells are filamentous. blood agar plates. At $37^{\circ} \mathrm{C}$ we observed strongly reduced growth and greyish and brown colonies with a clearing zone around colonies on this type of agar. In contrast, the $\Delta d o a 1$ mutants showed hyperfilamentous growth (as compared with the wild-type) with no or only reduced clear zones around the colonies at $30^{\circ} \mathrm{C}$. On YCB-BSA agar, which can be used to test extracellular proteolytic activity, we observed an earlier and stronger production of filaments for the $\Delta$ doa 1 mutants at $30^{\circ} \mathrm{C}$ compared with $37^{\circ} \mathrm{C}$ and with the wild-type under the same temperatures. Phenotypes of $\Delta$ doa 1 mutants are summarized in Table 3.

\section{Phospholipase activity of $\Delta$ doa1}

Since the human orthologue of CaDoa1, PLAP, is a phospholipase A2-activating factor, we investigated whether disruption of DOA1 has any influence on phospholipase activity in $C$. albicans. For these studies we tested LPC as substrate with culture supernatants and soluble intracellular protein samples after mechanical cell lysis as enzyme sources. These samples came from $C$. albicans cells grown under conditions which normally favour yeast growth. Since phospholipase activity may depend on the morphology of C. albicans cells and the phenotypic analysis of the $\Delta d o a 1$ mutant showed filamentation under conditions which normally favour yeast growth, we investigated the morphology of cells in each sample. Both wild-type (CAF2-1) and $\Delta$ doa 1 mutant (DK2) cells grew in the yeast form in Lee's medium at $\mathrm{pH} 4.5$ at $25^{\circ} \mathrm{C}$ (not shown). However, growth in SD medium at 30 and $37^{\circ} \mathrm{C}$ caused at least moderate filamentation of the $\Delta$ doal mutant (2-4\%; not shown). Generally, the phospholipase activity was reduced below 
(b)

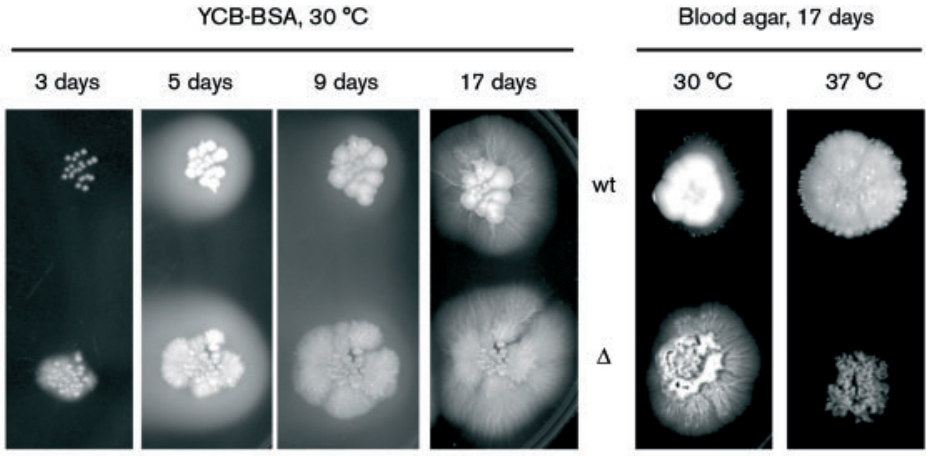

(c)
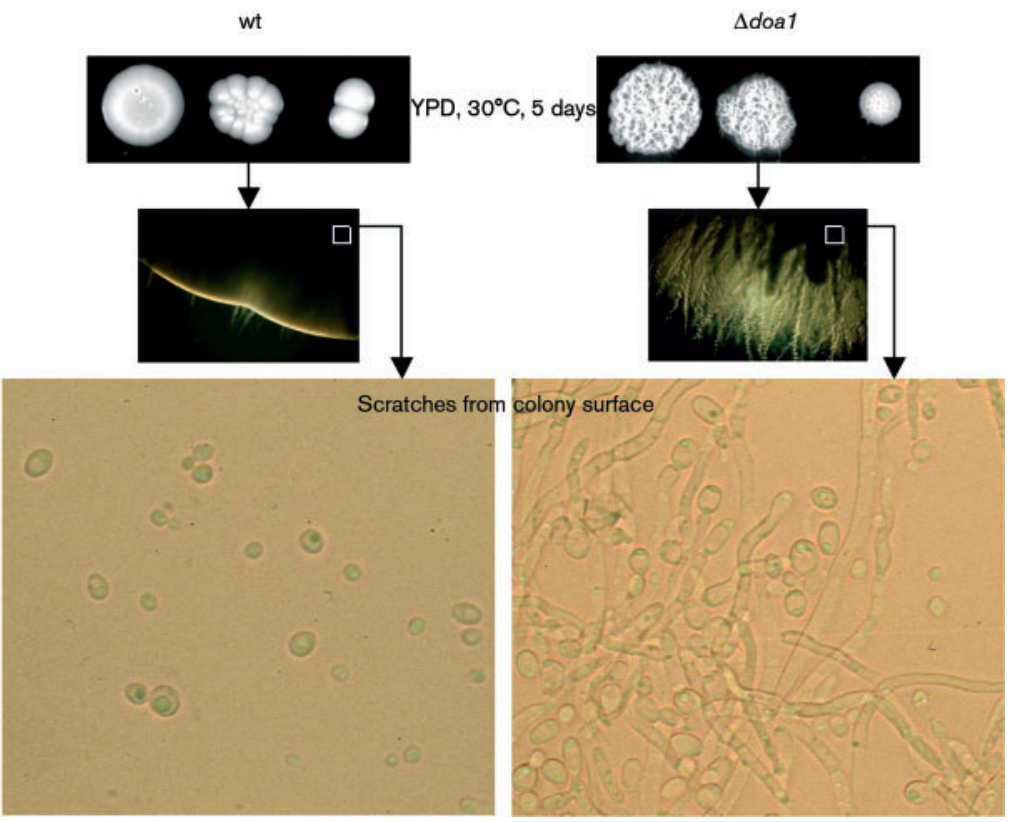

that of wild-type in SD medium. Extracellular phospholipase activity was reduced by $68.4 \pm 3.5 \%$ at $\mathrm{pH} 6.0$ and $68.5 \pm 2.8 \%$ at $\mathrm{pH} 7.5$ at $30{ }^{\circ} \mathrm{C}$. At $37^{\circ} \mathrm{C}$ the activity was further decreased $(78.5 \pm 1.0 \%$ at $\mathrm{pH} 6.0$ and $74.9 \pm 5.2 \%$ at $\mathrm{pH}$ 7.5). Intracellular phospholipase activity was reduced by $56.1 \pm 4.1 \%$ at $\mathrm{pH} 6.0$ and $49.4 \pm 1.9 \%$ at $\mathrm{pH} 7.5$ at $30{ }^{\circ} \mathrm{C}$. At $37^{\circ} \mathrm{C}$ the activity was less reduced $(25.4 \pm 7.3 \%$ at $\mathrm{pH} 6.0$ and $25.4 \pm 7.3 \%$ at $\mathrm{pH} 7.5$ ).

\section{Reintroduction of DOA1 into $\Delta$ doa1 restored wild-type phenotypes}

To fulfil Koch's postulates (Falkow, 1988), we reintroduced a native DOA 1 copy into the $\Delta$ doa 1 mutant (DK2) and investigated the phenotype of the retransformant (DK3) in comparison with the $\Delta$ doal mutant on selected media. For this we fused the DOA1 gene with the controllable PCK1 promoter from C. albicans into the plasmid pBI-1 (Leuker et al., 1997; Stoldt et al., 1997). Genes controlled by the PCK1 promoter are expressed under low concentrations of glucose. A PCR fragment containing the entire DOA1 ORF and $200 \mathrm{bp}$ of the untranslated $3^{\prime}$ region was cloned into pBI-1 to produce the retransformation plasmid $\mathrm{pDK}-22$. The
URA3-negative $\Delta$ doal mutant was transformed with $\mathrm{pDK}$ 22. To produce a control strain, we also transformed the URA3-negative $\Delta$ doal mutant with the empty plasmid pBI1. Transformants with the PCK1-driven DOA1 gene (DK3) and the mutant with the empty vector (DK5) were tested on media known to induce the $P C K 1$ promoter and containing compounds previously shown to inhibit growth of the $\Delta$ doal mutants. These included CAA medium, succinate medium (B medium), SGlycAc medium and CAA medium with isoflurane or itraconazole $\left(1 \mu \mathrm{g} \mathrm{ml}^{-1}\right)$ at 30 and $37^{\circ} \mathrm{C}$.

As shown in Fig. 5, extrachromosomal expression of DOA1 reversed the altered growth phenotypes of $D O A 1$ disruption on all media. To show further that the observed phenotypes of the $\Delta$ doal mutants were in fact due to the disruption of $D O A 1$, we also cloned DOA1 including its own promoter and $3^{\prime}$ untranslated region into the vector CIp10 (Murad et al., 2000) (to give $\mathrm{pDK}-24$ and $\mathrm{pDK}-25$ ) and inserted the gene into the RPS1 locus of $C$. albicans (DK8). When compared to strains carrying the empty plasmid CIp10 (DK7), transformants carrying pDK-25 (DK8) reversed the phenotype observed for $\Delta$ doal mutants into wild-type phenotypes (not shown). 
Table 3. Phenotypes of $\Delta d o a 1$ mutants on solid media

The following abbreviations and symbols are used to describe the phenotype of the mutant: $h f$, hyperfilamentation; -, no differences; in, growth inhibition; $c$, crumpled colony surface; $>c z$, increased clearing zone; ND, not determined.

\begin{tabular}{|c|c|c|}
\hline Growth condition and inhibitor & $30{ }^{\circ} \mathrm{C}$ & $37^{\circ} \mathrm{C}$ \\
\hline \multicolumn{3}{|l|}{ Standard media } \\
\hline SD & - & - \\
\hline YPD & $h f$ & $c$ \\
\hline Sabouraud & - & - \\
\hline YPD anaerobic & ND & hf \\
\hline \multicolumn{3}{|l|}{ Hyphal induction } \\
\hline Spider & $c$ & hf \\
\hline M199 & $h f$ & $h f$ \\
\hline FCS $(5 \%)$ & hf & hf \\
\hline FCS $(10 \%)$ & - & hf \\
\hline \multicolumn{3}{|l|}{ Extracellular hydrolytic activity } \\
\hline Blood agar & $h f$ & in, $c,>c z$ \\
\hline Egg yolk agar & $>c z$ & - \\
\hline YCB-BSA & $h f,>c z$ & hf \\
\hline \multicolumn{3}{|l|}{ Osmotic stress } \\
\hline Sorbitol $(6,7 \%)$ & - & - \\
\hline Galactose $(5 \%)$ & $h f$ & - \\
\hline $\mathrm{NaCl}(0.5-1.25 \mathrm{M})$ & - & - \\
\hline \multicolumn{3}{|l|}{ Oxidative stress } \\
\hline $\begin{array}{l}\text { Potassium acetate (2\%), } \\
\text { glycerol (3\%) (SGlycAc) }\end{array}$ & - & in \\
\hline $\begin{array}{l}\text { Potassium acetate }(2 \%) \text {, } \\
\text { glycerol }(3 \%)(\text { SGlycAc) } \\
\text { plus } \mathrm{CuCl}_{2}(10 \mathrm{mM})\end{array}$ & in & ND \\
\hline $\begin{array}{l}\text { Potassium acetate }(2 \%) \\
\text { glycerol }(3 \%) \text { (YGlycAc) }\end{array}$ & $c$ & $c$ \\
\hline $\mathrm{H}_{2} \mathrm{O}_{2}(0.44-0.88 \mathrm{mM})$ & in & ND \\
\hline \multicolumn{3}{|l|}{ pH sensitivity } \\
\hline pH 5.7 & $h f$ & - \\
\hline pH 6.0 & $h f$ & $c$ \\
\hline pH 6.5 & $h f$ & $c$ \\
\hline pH 7.0 & $h f$ & $c$ \\
\hline pH 7.5 & $h f$ & $c$ \\
\hline $\mathrm{pH} 8.0$ & $h f$ & - \\
\hline \multicolumn{3}{|l|}{ Chelators } \\
\hline $\begin{array}{l}\text { EDTA }(1 \mathrm{mM})\left(\mathrm{Mn}^{2+}, \mathrm{Ca}^{2+},\right. \\
\left.\mathrm{Mg}^{2+}, \mathrm{Ni}^{2+}, \mathrm{Zn}^{2+}\right)\end{array}$ & in & in \\
\hline Ciclopirox $\left(\mathrm{Fe}^{2+}\right)$ & - & - \\
\hline 2,2'-Dipyridyl $\left(\mathrm{Fe}^{2+}\right)$ & - & in \\
\hline \multicolumn{3}{|l|}{ Ions/signal transduction } \\
\hline $\mathrm{LiCl}(0.24 \mathrm{M})$ & ND & - \\
\hline $\mathrm{CaCl}_{2}(300 \mathrm{mM})$ & - & - \\
\hline $\mathrm{MnCl}_{2}(30 \mathrm{mM})$ & - & $c$ \\
\hline Caffeine $(10 \mathrm{mM})$ & - & in \\
\hline \multicolumn{3}{|l|}{ Heavy metals } \\
\hline Cadmium sulfate $(15-100 \mu \mathrm{M})$ & - & in \\
\hline Cadmium sulfate $(120 \mu \mathrm{M})$ & in & ND \\
\hline \multicolumn{3}{|l|}{ Protein synthesis inhibitors } \\
\hline Hygromycine B $\left(400 \mu \mathrm{g} \mathrm{ml}^{-1}\right)$ & - & in \\
\hline Cycloheximide $\left(1 \mu \mathrm{g} \mathrm{ml}^{-1}\right)$ & - & (in) \\
\hline
\end{tabular}

Table 3. cont.

\begin{tabular}{|c|c|c|}
\hline Growth condition and inhibitor & $30^{\circ} \mathrm{C}$ & $37^{\circ} \mathrm{C}$ \\
\hline Tetracycline $\left(10 \mu \mathrm{g} \mathrm{ml}^{-1}\right)$ & - & - \\
\hline \multicolumn{3}{|l|}{ Microtubule inhibitors } \\
\hline Nocodazole $\left(4 \mu \mathrm{g} \mathrm{ml}^{-1}\right)$ & - & in \\
\hline Benomyl $\left(10 \mu \mathrm{g} \mathrm{ml}^{-1}\right)$ & - & - \\
\hline \multicolumn{3}{|l|}{ Cell wall inhibitors } \\
\hline Calcofluor $\left(800 \mu \mathrm{g} \mathrm{ml}^{-1}\right)$ & - & in \\
\hline Congo Red (100 $\left.\mathrm{mg} \mathrm{ml}^{-1}\right)$ & - & ND \\
\hline \multicolumn{3}{|l|}{ Cell surface integrity } \\
\hline SDS $(0.005 \%)$ & in & in \\
\hline Amphotericin B $\left(0.2 \mu \mathrm{g} \mathrm{ml}^{-1}\right)$ & - & in \\
\hline Amorolfine $\left(3 \mu \mathrm{g} \mathrm{ml}^{-1}\right)$ & - & in \\
\hline Itraconazole $\left(1 \mu \mathrm{g} \mathrm{ml}^{-1}\right)$ & in & in \\
\hline Casamino acids plus itraconazole & in & - \\
\hline Succinate plus itraconazole & - & in \\
\hline \multicolumn{3}{|l|}{ Non-glucose carbon sources } \\
\hline Galactose $2 \%$ (SGal) & - & - \\
\hline Galactose $2 \%$ (YGal) & - & - \\
\hline Sucrose $2 \%$ (SSucr) & in & ND \\
\hline Casamino acids & $h f$ & $c$ \\
\hline Succinate & $h f$ & $c$ \\
\hline \multicolumn{3}{|l|}{ Calcineurine A inhibition } \\
\hline Cyclosporin A $\left(50-100 \mu \mathrm{g} \mathrm{ml}^{-1}\right)$ & - & - \\
\hline \multicolumn{3}{|l|}{ PLD and PA phosphatase inhibitors } \\
\hline Propranolol $(50-500 \mu \mathrm{M})$ & - & in \\
\hline Butanol $(0.5-5 \%)$ & in & in \\
\hline \multicolumn{3}{|l|}{ Volatile anaesthetics } \\
\hline Isoflurane $(100-500 \mu \mathrm{l})$ & in & ND \\
\hline
\end{tabular}

\section{The mellitin-like C-terminal region of Doa1 is essential for full function of Doa1}

Clark et al. (1991) investigated the role of the mellitin-like region of the PLAP protein for the activation of phospholipase A2. To investigate the functional role of the mellitin-like region downstream of the WD repeats we deleted a small region containing the KVL motif in the DOA1 gene sequence used to rescue the wild-type phenotype in the $\Delta$ doal mutant. This was accomplished using plasmid pDK-21 as a template for an inverse PCR with primers DOA1-kla fwd and rev. The resulting fragment lacking base pairs +1801 to +1875 after the ATG start codon of DOA1 (representing the amino acids of CaDoal shown in Fig. 1b) was fused to the PCK1 promoter in pBI-1 (pDK-27). Transformants (DK6) were analysed on PCK1-inducing media such as CAA, SGlycAc and blood agar at 30 and $37^{\circ} \mathrm{C}$ in serial drop dilution tests. As shown in Fig. 6, the PCK promoter-driven DOA1 gene lacking the $75 \mathrm{bp}$ fragment of the mellitin-like region was not able to fully restore the phenotypes of the $\Delta$ doal mutant on CAA (wildtype and retransformant have smooth surfaces, mutants have wrinkled surfaces) and blood agar (wild-type and retransformant produce smooth colony edges, mutants produce hyphae at the edge of the colony), suggesting that this region is essential for full function of CaDoal. 
$30^{\circ} \mathrm{C}, 5$ days
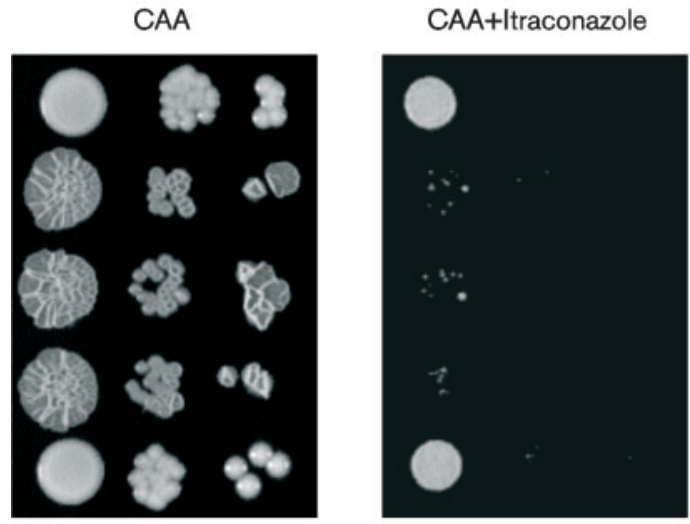

CAF 2-1

$\Delta d o a 1 / \Delta d o a 1$

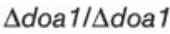

$\Delta$ doa $1 / \Delta$ doa $1+\mathrm{pB} \mid-1$

$\Delta$ doa1/ $\Delta$ doa1+pBI-1-DOA1

$37^{\circ} \mathrm{C}, 6$ days

B-Medium
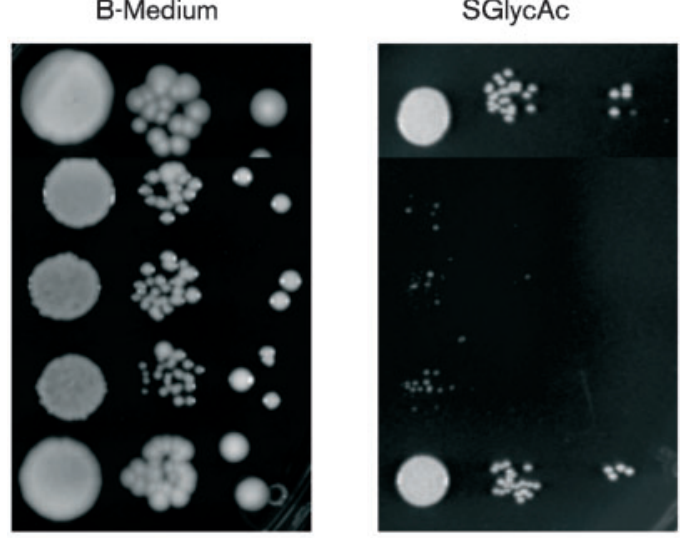

CAF 2-1

$\Delta d o a 1 / \Delta d o a 1$

$\Delta d o a 1 / \Delta d o a 1$

$\Delta d o a 1 / \Delta d o a 1+p B \mid-1$

$\Delta$ doa1/ $\Delta$ doa1+pBI-1-DOA1

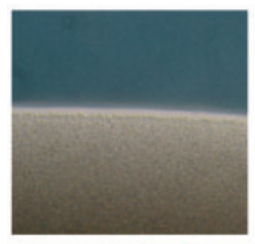

CAF 2-1

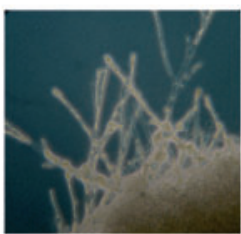

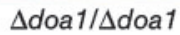

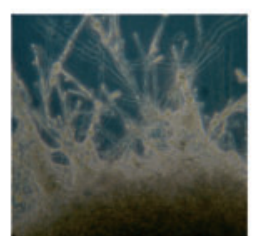

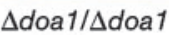
$+\mathrm{pBI}-1$

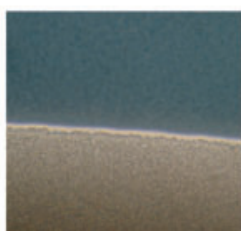

$\Delta$ doa1/ $/$ doa1 $+\mathrm{pBI}-1-D O A 1$
Fig. 5. Reintroduction of $D O A 1$ into $\triangle d o a 1$ restored wild-type phenotypes. A native copy of DOA1 was fused to the PCK1 promoter in the plasmid $\mathrm{pBI}-1$ and cultivated under conditions which promoted PCK1 induction. Growth of the retransformant $(\Delta$ doa1/ $\Delta$ doa1 + pBI-1-DOA1) was compared with the $\Delta$ doa 1 mutant carrying the empty plasmid $(\Delta$ doa $1 / \Delta$ doa $1+\mathrm{pBI}-1)$ and two isogenic mutants $(\Delta d o a 1 / \Delta$ doa 1 , carrying one copy of URA3). The wild-type phenotype (growth rate, colony morphology and cell morphology) was recovered in CAA medium, CAA containing itraconazole, B medium and medium containing glycerol and acetate as carbon source (SGlycAc).

\section{Overexpression of DOA1 has no influence on wild-type cells}

Since disruption of $D O A 1$ generated altered phenotypes we questioned whether overexpression of DOA1 may have an influence on cellular processes and growth. Therefore, we transformed the wild-type strain CAI- 4 with plasmid pDK22 containing the $P C K 1$ promoter-driven DOA1 gene in pBI-1. Transformants (DK4) grown on SD, YPD, B medium, CAA medium, B medium or CAA medium containing $1 \mu \mathrm{g}$ itraconazole $\mathrm{ml}^{-1}$, SGlycAc medium and 5 or $10 \%$ FCS agar at 30 or $37^{\circ} \mathrm{C}$ did not show any growth differences when compared to strains carrying empty pBI-1.

\section{DOA1 transcription under selected growth conditions}

Phenotypic analysis of $\Delta$ doa 1 mutants showed that disruption of $D O A 1$ caused multiple growth effects under distinct conditions. Since we reasoned that DOA1 might be regulated under the conditions which caused growth defects for $\Delta$ doa 1 mutants, we investigated the transcriptional levels under selected conditions, such as SD medium containing $60 \mu \mathrm{M} \mathrm{CdSO}_{4}$ or SGlyc medium at $37^{\circ} \mathrm{C}$, as compared with mRNA levels in SD medium at $37^{\circ} \mathrm{C}$ in wild-type cells. Furthermore, we monitored the transcript level in SD medium at $42{ }^{\circ} \mathrm{C}$. Only this heat-shock condition caused an increased transcriptional level of DOA1 (Fig. 7).

\section{Transcriptional profiling of $\Delta d o a 1$}

To obtain further information about the functions of $D O A 1$, we investigated the genome-wide transcription profile of the $\Delta$ doal mutant (DK2) as compared to the wild-type strain CAF2-1 using microarrays. Cells from the $\Delta$ doal mutant and the wild-type strain CAF2-1 were precultured in SD at $30^{\circ} \mathrm{C}$, and $10^{6}$ cells $\mathrm{ml}^{-1}$ were inoculated in SD medium at 
$\mathrm{SD} 37^{\circ} \mathrm{C}$

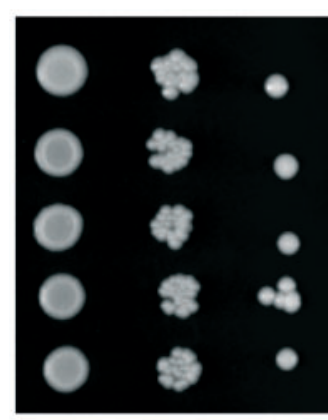

Blood agar $37^{\circ} \mathrm{C}$

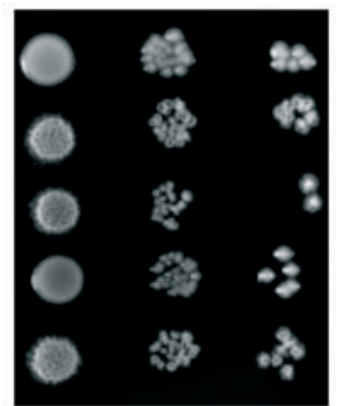

Blood agar $30^{\circ} \mathrm{C}$

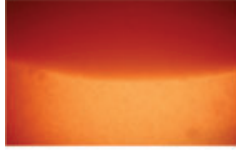

CAF 2-1

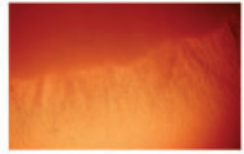

$\Delta$ doa1

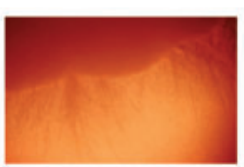

$\Delta$ doa $1+\mathrm{pBI}-1$

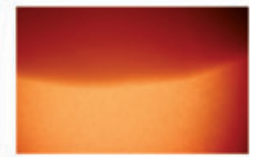

$\Delta$ doa1 $\quad \Delta$ doa1

$+\mathrm{pBI}-1-D O A 1 \quad+\mathrm{pBI}-1-D O A 1-\mathrm{KVL}$

Fig. 6. Removal of a small mellitin-like region containing the conserved KVL motif caused loss of full function of Doa1. Strains containing a $D O A 1$ gene without this region $(\triangle d o a 1+\mathrm{pBI}-1-D O A 1-\mathrm{KVL})$ are not able to fully restore the wild-type phenotype in CAA (colony morphology) and blood agar (colony and cell morphology) as compared with the wild-type and the retransformant strain containing the native gene $(\Delta d o a 1+\mathrm{pBI}-1-D O A 1)$.

$37^{\circ} \mathrm{C}$ for $7 \mathrm{~h}$ before RNA was isolated. Transcriptional array data confirmed the expression data obtained with RTPCR. Including the genes investigated by RT-PCR, 96 genes were significantly differentially expressed in both strains $(P<0.05, t$-test $)$. Genes were 11.1- to 1.4 -fold differentially expressed. Only two genes were identified as downregulated (both 2.1-fold) (Table 4). Fig. 8 shows the functional categories to which the 96 differentially expressed genes could be associated. One-third of all the genes (36 genes) encode proteins of unknown function (Fig. 8). Beside this group, the largest group of genes is associated with protein degradation, mostly linked to the proteosome, Ub or Ubindependent proteolysis. Other functional groups were transcription and replication, transport, fat metabolism and energy, amino acid metabolism, stress and oxidative stress. Despite the fact that the mutant produced mainly pseudohypha and few true hypha, we identified the true hypha-associated gene $H W P 1$ as being upregulated. For selected genes (HWP1, RBT6, ACB1, PRE10, PRE6, SMT3, IPF3262 and IPF3262) we again used RT-PCR to verify the microarray data (not shown).

\section{Virulence of $\Delta d o a 1$}

Since disruption of DOA1 caused multiple phenotypes, including hyperfilamentation, we analysed the virulence of mutants lacking DOA1 (DK2) by intravenous challenge in mice. Despite the filamentous phenotypic tendency of the $\Delta$ doal mutant, no significant differences were observed in terms of mouse survival and organ burden compared with wild-type strain CAF2-1. Cell morphologies in the inoculum suspension comprised only yeast forms and short pseudo-
SGlyc CD $37^{\circ} \mathrm{C} 42^{\circ} \mathrm{C}$
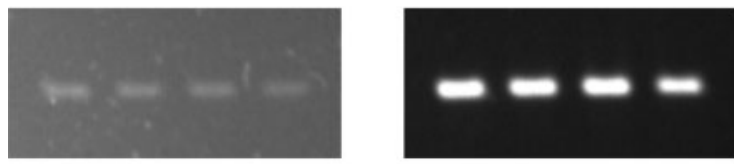

ACT1

20 and 25 cycles
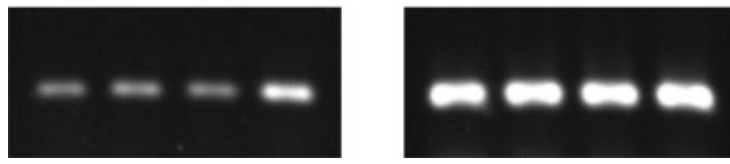

$D O A 1$

30 and 35 cycles
Fig. 7. Transcriptional level of $D O A 1$ as measured by semiquantitative RT-PCR in wild-type cells under selected conditions such as SD medium at 37 or $42{ }^{\circ} \mathrm{C}$, SD medium containing $\mathrm{CdSO}_{4}(\mathrm{CD})$ or SGlyc medium (SGlyc) as compared to the expression of the housekeeping gene ACT1. Only an increased temperature caused higher expression levels of $D O A 1$. 
Table 4. Genes differentially expressed in $\Delta$ doa 1

\begin{tabular}{|c|c|c|}
\hline $\begin{array}{l}\text { Proteosome, Ub-dependent or } \\
\text {-independent proteolysis (13) }\end{array}$ & Transcription/DNA/RNA (11) & Transporter (7) \\
\hline $\begin{array}{l}\text { PUP2, UBI4, SMT3, CDC48, } \\
\text { PRE6, PRE10, RPT1, RPT3, } \\
\text { RPT6, IPF19983, IPF13356, } \\
\text { IPF7227, IPF3262.3 }\end{array}$ & $\begin{array}{l}\text { HIR1(down), RNR21, DCP1, IFA3, URA5, MBF1, } \\
\text { Zorro1a, IPF19974, IPF7666, IPF4814, IPF14248 }\end{array}$ & $\begin{array}{l}\text { CAN2, GAP6, GAP3, SSU1, CAF16, } \\
\text { TOM22, GAP7.3eoc }\end{array}$ \\
\hline$Y H B 1, E B P 1, P C K 1, G P M 2, P G M 2$ & ACB1.exon2, SCS7, MUQ1, ARE2, DAK2.3eoc & TTR1, TRR1, IPF6231 \\
\hline $\begin{array}{l}\text { Stress/chaperones (2) } \\
C P R 6, R B L 2\end{array}$ & $\begin{array}{l}\text { Hypha specific (1) } \\
\text { HWP1 }\end{array}$ & $\begin{array}{l}\text { Amino acid biosynthesis/metabolism (2) } \\
\text { MET3 (down), IPF } 13176.3\end{array}$ \\
\hline $\begin{array}{l}\text { Unspecific (several) functions (11) } \\
E R O 1, U G P 1, H E M 14, M A K 3 \text {, } \\
\text { CRD1, IPF199, IPF6041, IPF7400, } \\
\text { IPF11379, IPF3492, IPF1969 }\end{array}$ & 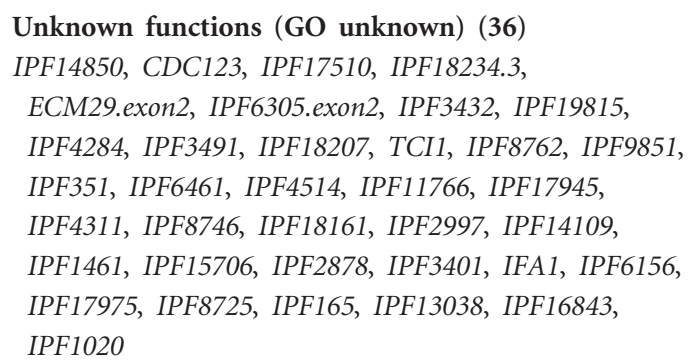 & \\
\hline
\end{tabular}

hyphae. The cells in the kidneys of moribund animals were filamentous, as were those in the kidneys of animals infected with wild-type $C$. albicans.

\section{DISCUSSION}

The aim of this study was the identification and characterization of putative regulators of virulence attributes, such as phospholipase A activity in C. albicans. One of the genes identified was similar to the human gene PLAP known to be associated with the regulation of phospholipase A activity (Lis \& Romesberg, 2006) and Doal in S. cerevisiae (Tzermia et al., 1994). Due to the high level of similarity to ScDOA1, we named this gene $(\mathrm{Ca}) \mathrm{DOA} 1$. Although DOA1 was transcribed under all conditions investigated in yeast and pseudohyphal/filamentous forms of $C$. albicans, this gene is not essential for growth as mutants lacking DOA1 were viable. It is not clear whether $D O A 1$ has a direct influence on phospholipase activity; however, $\Delta$ doal mutants had reduced phospholipase activity.

The Doal amino acid sequence showed strong similarities to members of the WD-repeat protein family. These proteins have diverse cellular functions, such as regulation of signal transduction, transcription, pre-mRNA processing or cytoskeleton assembly (Smith et al., 1999). Typically, WDrepeat proteins do not have catalytic functions, but are involved in multi-protein complexes in direct interaction with other proteins via the WD repeats (Neer et al., 1994). However, some WD-repeat proteins are fused to a functional domain and have catalytic activities, for example the mammalian protein PLAP (Neer et al., 1994). In PLAP, the functional domain contains a mellitin-like sequence (Clark et al., 1991) which is used to activate phospholipase $\mathrm{A}_{2}$. A similar sequence exists in CaDoal as shown in this study. We showed that this putatively catalytic domain is essential for full function in C. albicans. Therefore, it may be possible that Doal in $C$. albicans has a catalytic function. The protein with the highest overall similarity to CaDoal is ScDoa1. Similar to CaDoa1, the second and seventh WD repeat of ScDoal (Keil et al., 1996) differ in the consensus

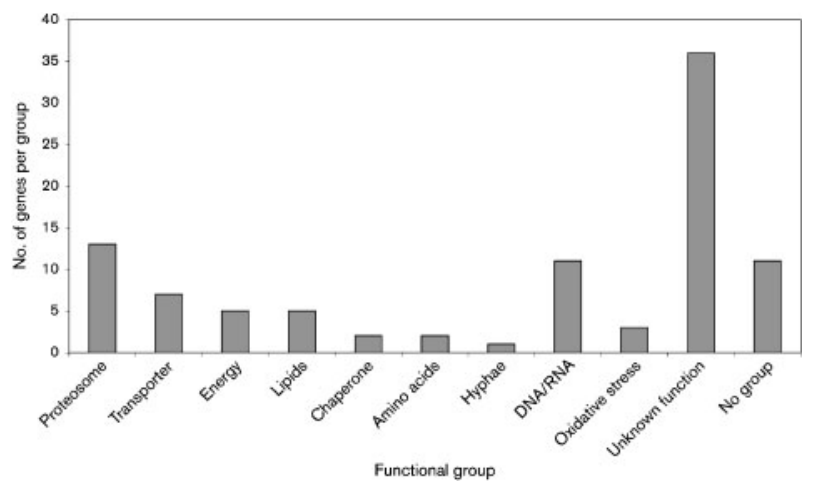

Fig. 8. Functional categories of genes upregulated in the $\Delta$ doa1 mutant in SD medium at $37^{\circ} \mathrm{C}$ compared with wild-type cells as monitored by microarray analysis. Only two genes, MET3 and HIR1, out of 96 differentially expressed genes were found to be downregulated. 
sequence, confirming relatively high similarity between these two orthologues. However, the most similar regions between ScDoal and the mammalian PLAP are beyond the WD repeats in the C-terminal part, but exclude the catalytic mellitin-like sequence of PLAP. In contrast, CaDoal and PLAP are more similar within the mellitin-like sequence.

ScDoal has been shown to play a key role during Ubdependent protein degradation, regulation of the cellular Ub concentration and DNA damage response (Johnson et al., 1995; Lis \& Romesberg, 2006). In two hybrid assays, ScDoa1 bound to $\mathrm{Cdc} 48$ and other factors via the $\mathrm{C}$ terminus (Decottignies et al., 2004; Ghislain et al., 1996; Johnson et al., 1995; Keil et al., 1996; Seigneurin-Berny et al., 2001). The human orthologue of the chaperone Cdc48 is a central element in a major Ub-associated escort pathway (Rumpf \& Jentsch, 2006). Recently, Mullally et al. (2006) showed that ScDoal is a Cdc48 adaptor that possesses a novel Ub binding domain. A number of phenotypes and the transcript profiles of mutants lacking CaDoal suggest that this orthologue in C. albicans has both distinct and similar functions and may also be involved in ubiquitination.

Deletion of ScDOA1 caused resistance to isoflurane and other anaesthetics, and increased sensitivity to cadmium (Keil et al., 1996; Wolfe et al., 1998). The $\Delta$ doa 1 mutant of $C$. albicans is moderately more sensitive to both isoflurane and cadmium. The mode of action of isoflurane on fungal cells is unclear; however, an influence of isoflurane on membrane lipids and proteins, and on their role in membrane integrity has been proposed (Keil et al., 1996). In contrast, Wolfe et al. (1998) postulated a possible direct or indirect correlation with Ub metabolism. Likewise, sensitivity to cadmium can be linked to Ub-mediated proteolysis. Cadmium reacts with thiol groups of proteins and can substitute $\mathrm{Zn}^{2+}$ ions. These modified proteins are likely to be substrates for proteolytic degradation via the proteosome. For example, mutants lacking Ub-conjugating proteins such as Ubc1, Ubc4 and Ubc7, or subunits of the proteosome such as Prel are hypersensitive to cadmium in S. cerevisiae (Jungmann et al., 1993).

Microarray analyses of the $\Delta$ doa 1 mutant further hint at a role of Doal in the Ub degradation pathway. Several genes upregulated in the mutant are linked with Ub degradation. Of particular interest are UBI4 and CDC48.

Overexpression of ScUBI4 complements the defects of $\Delta$ doal in S. cerevisiae (Johnson et al., 1995) and the orthologue of UBI4 from C. albicans can complement the defects of $\Delta u b i 4$ in S. cerevisiae (Roig \& Gozalbo, 2003). C. albicans wild-type cells upregulate UBI4 during thermal stress and starvation, and mutants lacking Ubi4 have a moderately increased sensitivity to heat shock (Roig \& Gozalbo, 2003). However, $\Delta u b i 4$ mutants of C. albicans have a clear morphological dysfunction as increased formation of hyphal and pseudohyphal cells was observed (Roig \& Gozalbo, 2003). The same expression pattern and phenotypes were shown for $\Delta$ doal in this study.
As mentioned above, Mullally et al. (2006) suggest that ScDoal acts as an adaptor between Cdc48 and Ub. CDC48 is upregulated in the $\Delta$ doal mutant of $C$. albicans and, due to the high similarities between ScDoal and CaDoal, it is likely that CaDoal has similar functions within the Ub degradation pathway. In this context, it is worth mentioning that the Ub binding domain in ScDoa1, the PFU domain (Mullally et al., 2006), is also conserved in CaDoal (aa 354-448).

However, in addition to the similar features, there must be differences in function since the most obvious phenotype of the $\Delta$ doal mutant of $C$. albicans was filamentous growth under conditions that normally support yeast morphology. These filaments were a mixture of true hyphae and pseudohyphae as indicated by the location of septa within the filaments (Sudbery, 2001). Surprisingly, we observed that the known hypha-specific gene HWP1 was upregulated in the $\Delta$ doal mutant compared to wild-type cells, even though the mutant cells grew mostly as pseudohyphae at the time of sampling.

Filamentous phenotypes have been observed in a number of mutants, such as strains lacking SSN6 (Hwang et al., 2003), SPT3 (Laprade et al., 2002), UBI4 (Roig \& Gozalbo, 2003), RAD6 (Leng et al., 2000), CDC4 (Atir-Lande et al., 2005) and GRR1 (Butler et al., 2006) in C. albicans, with the last four genes putatively linked to the Ub degradation pathway. Therefore, ubiquitination seems to be an important and previously underestimated regulator of morphology in $C$. albicans.

In addition to the filamentous morphology, we observed further phenotypes for the $\Delta$ doal mutant of C. albicans, which were not described for the corresponding mutant in S. cerevisiae. For example, Ghislain et al. (1996) did not observe reduced growth for mutants lacking Doa1 (Ufd3) in S. cerevisiae when cells were exposed to caffeine (inhibitor of cAMP phosphodiesterase), while growth of the $\Delta$ doa 1 mutant of $C$. albicans was dramatically reduced when exposed to caffeine. Furthermore, propranolol, an inhibitor of phosphatidate phosphohydrolase, the enzyme which can convert PA to DAG, strongly reduced growth of $\Delta$ doal. DAG, which can also be produced by phosphatidate phosphohydrolase-independent pathways, is an essential molecule for certain molecular processes (Kearns et al., 1997). It was suggested to be a regulator of morphology in $C$. albicans as mutants lacking phospholipase $\mathrm{D}$, which cannot produce PA from PC, have reduced abilities to produce hyphae (Hube et al., 2001). Since propranolol had such a strong effect on growth, it must be concluded that other pathways of DAG production, such as PLC-mediated activity, are blocked or inhibited in the $\Delta$ doal mutant.

Several observations, including increased susceptibility to SDS, amphotericin B, amorolfine or itraconazole, suggest a defect of the $\Delta$ doal mutant in cell surface integrity. These defects could also be responsible for the reduced haemolytic activity observed on blood agar. Furthermore, cell membrane or cell wall defects may have caused reduced 
protection against extracellular exposure to inhibitors, such as cycloheximide and hygromycin B, which cause increased growth inhibition in the $\Delta$ doal mutant. The view that disruption of $D O A 1$ caused a defect in membrane integrity was supported by the observation that genes associated with sterol metabolism, such as SCS7 or ACB1 (Faergeman et al., 2004; Gaigg et al., 2001; Jensen-Pergakes et al., 2001; Swain et al., 2002; Yang et al., 1996), or oxidative or nitrogen stress, such as TTR1, TRR1 (Fradin et al., 2005) or YHB1 (Hromatka et al., 2005), were upregulated in the mutant.

Although the $\Delta$ doal mutant had severe growth defects under a number of conditions and was filamentous, the virulence in a mouse model of systemic infections was not attenuated. Since both yeast and filamentous cell forms seem to be essential for full virulence in C. albicans (Kumamoto \& Vinces, 2005a, b) it must be concluded that other factors compensate the loss of function of Doal in vivo.

\section{ACKNOWLEDGEMENTS}

We thank members of the NG5 team of Antje Flieger, Robert KochInstitut, for help with the phospholipase assay. This work was supported by the Robert Koch-Institut and the Deutsche Forschungsgemeinschaft (Hu528/7)

\section{REFERENCES}

Amerik, A. Y., Li, S. J. \& Hochstrasser, M. (2000). Analysis of the deubiquitinating enzymes of the yeast Saccharomyces cerevisiae. Biol Chem 381, 981-992.

Atir-Lande, A., Gildor, T. \& Kornitzer, D. (2005). Role for the SCFCDC4 ubiquitin ligase in Candida albicans morphogenesis. Mol Biol Cell 16, 2772-2785.

Baker, C. A., Desrosiers, K. \& Dolan, J. W. (2002). Propranolol inhibits hyphal development in Candida albicans. Antimicrob Agents Chemother 46, 3617-3620.

Buffo, J., Herman, M. A. \& Soll, D. R. (1984). A characterization of $\mathrm{pH}$-regulated dimorphism in Candida albicans. Mycopathologia 85, 21-30.

Butler, D. K., All, O., Goffena, J., Loveless, T., Wilson, T. \& Toenjes, K. A. (2006). The GRR1 gene of Candida albicans is involved in the negative control of pseudohyphal morphogenesis. Fungal Genet Biol 43, 573-582.

Calderone, R. A. \& Fonzi, W. A. (2001). Virulence factors of Candida albicans. Trends Microbiol 9, 327-335.

Castrillo, J. I. \& Oliver, S. G. (2006). Metabolomics and systems biology in Saccharomyces cerevisiae. In Fungal Genomics (The Mycota, Vol. 13), pp. 3-18. Edited by A. Brown. Berlin, Heidelberg: Springer.

Clark, M. A., Ozgur, L. E., Conway, T. M., Dispoto, J., Crooke, S. T. \& Bomalaski, J. S. (1991). Cloning of a phospholipase A2-activating protein. Proc Natl Acad Sci U S A 88, 5418-5422.

De Backer, M. D., Maes, D., Vandoninck, S., Logghe, M., Contreras, R. \& Luyten, W. H. (1999). Transformation of Candida albicans by electroporation. Yeast 15, 1609-1618.

Decottignies, A., Evain, A. \& Ghislain, M. (2004). Binding of Cdc48p to a ubiquitin-related UBX domain from novel yeast proteins involved in intracellular proteolysis and sporulation. Yeast 21, 127-139.
Emanuelsson, O., Nielsen, H., Brunak, S. \& von Heijne, G. (2000). Predicting subcellular localization of proteins based on their Nterminal amino acid sequence. J Mol Biol 300, 1005-1016.

Faergeman, N. J., Feddersen, S., Christiansen, J. K., Larsen, M. K., Schneiter, R., Ungermann, C., Mutenda, K., Roepstorff, P. \& Knudsen, J. (2004). Acyl-CoA-binding protein, Acblp, is required for normal vacuole function and ceramide synthesis in Saccharomyces cerevisiae. Biochem J 380, 907-918.

Falkow, S. (1988). Molecular Koch's postulates applied to microbial pathogenicity. Rev Infect Dis 10 (Suppl. 2), S274-S276.

Falquet, L., Pagni, M., Bucher, P., Hulo, N., Sigrist, C. J., Hofmann, K. \& Bairoch, A. (2002). The PROSITE database, its status in 2002. Nucleic Acids Res 30, 235-238.

Felk, A., Kretschmar, M., Albrecht, A., Schaller, M., Beinhauer, S., Nichterlein, T., Sanglard, D., Korting, H. C., Schafer, W. \& Hube, B. (2002). Candida albicans hyphal formation and the expression of the Efg1-regulated proteinases Sap4 to Sap6 are required for the invasion of parenchymal organs. Infect Immun 70, 3689-3700.

Fonzi, W. A. \& Irwin, M. Y. (1993). Isogenic strain construction and gene mapping in Candida albicans. Genetics 134, 717-728.

Fradin, C., De Groot, P., MacCallum, D., Schaller, M., Klis, F., Odds, F. C. \& Hube, B. (2005). Granulocytes govern the transcriptional response, morphology and proliferation of Candida albicans in human blood. Mol Microbiol 56, 397-415.

Fu, Y., Ibrahim, A. S., Fonzi, W., Zhou, X., Ramos, C. F. \& Ghannoum, M. A. (1997). Cloning and characterization of a gene (LIP1) which encodes a lipase from the pathogenic yeast Candida albicans. Microbiology 143, 331-340.

Gaigg, B., Neergaard, T. B., Schneiter, R., Hansen, J. K., Faergeman, N. J., Jensen, N. A., Andersen, J. R., Friis, J., Sandhoff, R. \& other authors (2001). Depletion of acyl-coenzyme A-binding protein affects sphingolipid synthesis and causes vesicle accumulation and membrane defects in Saccharomyces cerevisiae. Mol Biol Cell 12, 1147-1160.

Ghannoum, M. A. (2000). Potential role of phospholipases in virulence and fungal pathogenesis. Clin Microbiol Rev 13, 122-143.

Ghislain, M., Dohmen, R. J., Levy, F. \& Varshavsky, A. (1996). Cdc48p interacts with Ufd3p, a WD repeat protein required for ubiquitin-mediated proteolysis in Saccharomyces cerevisiae. EMBO J 15, 4884-4899.

Gillum, A. M., Tsay, E. Y. \& Kirsch, D. R. (1984). Isolation of the Candida albicans gene for orotidine- $5^{\prime}$-phosphate decarboxylase by complementation of $S$. cerevisiae ura3 and E. coli pyrF mutations. Mol Gen Genet 198, 179-182.

Goyal, S. \& Khuller, G. K. (1992). Phospholipid composition and subcellular distribution in yeast and mycelial forms of Candida albicans. J Med Vet Mycol 30, 355-362.

Hochstrasser, M. \& Varshavsky, A. (1990). In vivo degradation of a transcriptional regulator: the yeast alpha 2 repressor. Cell 61, 697-708.

Hofmann, R. M. \& Pickart, C. M. (2001). In vitro assembly and recognition of Lys-63 polyubiquitin chains. J Biol Chem 276, 27936-27943.

Hromatka, B. S., Noble, S. M. \& Johnson, A. D. (2005). Transcriptional response of Candida albicans to nitric oxide and the role of the YHB1 gene in nitrosative stress and virulence. Mol Biol Cell 16, 4814-4826.

Hube, B., Monod, M., Schofield, D. A., Brown, A. J. \& Gow, N. A. (1994). Expression of seven members of the gene family encoding secretory aspartyl proteinases in Candida albicans. Mol Microbiol 14, 87-99.

Hube, B., Stehr, F., Bossenz, M., Mazur, A., Kretschmar, M. \& Schafer, W. (2000). Secreted lipases of Candida albicans: cloning, 
characterisation and expression analysis of a new gene family with at least ten members. Arch Microbiol 174, 362-374.

Hube, B., Hess, D., Baker, C. A., Schaller, M., Schafer, W. \& Dolan, J. W. (2001). The role and relevance of phospholipase D1 during growth and dimorphism of Candida albicans. Microbiology 147, 879-889.

Hwang, C. S., Oh, J. H., Huh, W. K., Yim, H. S. \& Kang, S. O. (2003). Ssn6, an important factor of morphological conversion and virulence in Candida albicans. Mol Microbiol 47, 1029-1043.

Jensen-Pergakes, K., Guo, Z., Giattina, M., Sturley, S. L. \& Bard, M. (2001). Transcriptional regulation of the two sterol esterification genes in the yeast Saccharomyces cerevisiae. J Bacteriol 183, 4950-4957.

Johnson, E. S., Ma, P. C., Ota, I. M. \& Varshavsky, A. (1995). A proteolytic pathway that recognizes ubiquitin as a degradation signal. J Biol Chem 270, 17442-17456.

Jones, T., Federspiel, N. A., Chibana, H., Dungan, J., Kalman, S., Magee, B. B., Newport, G., Thorstenson, Y. R., Agabian, N. \& other authors (2004). The diploid genome sequence of Candida albicans. Proc Natl Acad Sci U S A 101, 7329-7334.

Jungmann, J., Reins, H. A., Schobert, C. \& Jentsch, S. (1993). Resistance to cadmium mediated by ubiquitin-dependent proteolysis. Nature 361, 369-371.

Kearns, B. G., McGee, T. P., Mayinger, P., Gedvilaite, A., Phillips, S. E., Kagiwada, S. \& Bankaitis, V. A. (1997). Essential role for diacylglycerol in protein transport from the yeast Golgi complex. Nature 387, 101-105.

Keil, R. L., Wolfe, D., Reiner, T., Peterson, C. J. \& Riley, J. L. (1996). Molecular genetic analysis of volatile-anesthetic action. Mol Cell Biol 16, 3446-3453.

Knechtle, P., Goyard, S., Brachat, S., Ibrahim-Granet, O. \& d'Enfert, C. (2005). Phosphatidylinositol-dependent phospholipases C Plc2 and Plc3 of Candida albicans are dispensable for morphogenesis and hostpathogen interaction. Res Microbiol 156, 822-829.

Kumamoto, C. A. \& Vinces, M. D. (2005a). Contributions of hyphae and hypha-co-regulated genes to Candida albicans virulence. Cell Microbiol 7, 1546-1554.

Kumamoto, C. A. \& Vinces, M. D. (2005b). Alternative Candida albicans lifestyles: growth on surfaces. Annu Rev Microbiol 59, 113-133.

Kunze, D., Melzer, I., Bennett, D., Sanglard, D., MacCallum, D., Nörskau, J., Coleman, D. C., Odds, F. C., Schäfer, W. \& Hube, B. (2005). Functional analysis of the phospholipase C gene CaPLC1 and two unusual phospholipase $\mathrm{C}$ genes, CaPLC2 and CaPLC3, of Candida albicans. Microbiology 151, 3381-3394.

Laprade, L., Boyartchuk, V. L., Dietrich, W. F. \& Winston, F. (2002). Spt3 plays opposite roles in filamentous growth in Saccharomyces cerevisiae and Candida albicans and is required for C. albicans virulence. Genetics 161, 509-519.

Leng, P., Sudbery, P. E. \& Brown, A. J. (2000). Rad6p represses yeasthypha morphogenesis in the human fungal pathogen Candida albicans. Mol Microbiol 35, 1264-1275.

Leuker, C. E., Sonneborn, A., Delbruck, S. \& Ernst, J. F. (1997). Sequence and promoter regulation of the PCK1 gene encoding phosphoenolpyruvate carboxykinase of the fungal pathogen Candida albicans. Gene 192, 235-240.

Lis, E. T. \& Romesberg, F. E. (2006). Role of Doal in the Saccharomyces cerevisiae DNA damage response. Mol Cell Biol 26, 4122-4133.

Liu, H., Kohler, J. \& Fink, G. R. (1994). Suppression of hyphal formation in Candida albicans by mutation of a STE12 homolog. Science 266, 1723-1726.

Lo, H. J., Kohler, J. R., DiDomenico, B., Loebenberg, D., Cacciapuoti, A. \& Fink, G. R. (1997). Nonfilamentous C. albicans mutants are avirulent. Cell 90, 939-949.
Mullally, J. E., Chernova, T. \& Wilkinson, K. D. (2006). Doa1 is a Cdc48 adaptor that possesses a novel ubiquitin binding domain. Mol Cell Biol 26, 822-830.

Murad, A. M., Lee, P. R., Broadbent, I. D., Barelle, C. J. \& Brown, A. J. (2000). CIp10, an efficient and convenient integrating vector for Candida albicans. Yeast 16, 325-327.

Naglik, J. R., Challacombe, S. J. \& Hube, B. (2003). Candida albicans secreted aspartyl proteinases in virulence and pathogenesis. Microbiol Mol Biol Rev 67, 400-428.

Neer, E. J., Schmidt, C. J., Nambudripad, R. \& Smith, T. F. (1994). The ancient regulatory-protein family of WD-repeat proteins. Nature 371, 297-300.

Peitsch, M. C., Borner, C. \& Tschopp, J. (1993). Sequence similarity of phospholipase A2 activating protein and the $G$ protein betasubunits: a new concept of effector protein activation in signal transduction? Trends Biochem Sci 18, 292-293.

Pickart, C. M. (1997). Targeting of substrates to the $26 \mathrm{~S}$ proteasome. FASEB J 11, 1055-1066.

Roig, P. \& Gozalbo, D. (2003). Depletion of polyubiquitin encoded by the UBI4 gene confers pleiotropic phenotype to Candida albicans cells. Fungal Genet Biol 39, 70-81.

Rumpf, S. \& Jentsch, S. (2006). Functional division of substrate processing cofactors of the ubiquitin-selective Cdc48 chaperone. Mol Cell 21, 261-269.

Sanglard, D., Hube, B., Monod, M., Odds, F. C. \& Gow, N. A. (1997), A triple deletion of the secreted aspartyl proteinase genes SAP4, SAP5, and SAP6 of Candida albicans causes attenuated virulence. Infect Immun 65, 3539-3546.

Schaller, M., Korting, H. C., Schafer, W., Bastert, J., Chen, W. \& Hube, B. (1999). Secreted aspartic proteinase (Sap) activity contributes to tissue damage in a model of human oral candidosis. Mol Microbiol 34, 169-180.

Seigneurin-Berny, D., Verdel, A., Curtet, S., Lemercier, C., Garin, J., Rousseaux, S. \& Khochbin, S. (2001). Identification of components of the murine histone deacetylase 6 complex: link between acetylation and ubiquitination signaling pathways. Mol Cell Biol 21, 8035-8044.

Sigle, H. C., Thewes, S., Niewerth, M., Korting, H. C., SchaferKorting, M. \& Hube, B. (2005). Oxygen accessibility and iron levels are critical factors for the antifungal action of ciclopirox against Candida albicans. J Antimicrob Chemother 55, 663-673.

Smith, T. F., Gaitatzes, C., Saxena, K. \& Neer, E. J. (1999). The WD repeat: a common architecture for diverse functions. Trends Biochem Sci 24, 181-185.

Stoldt, V. R., Sonneborn, A., Leuker, C. E. \& Ernst, J. F. (1997). Efglp, an essential regulator of morphogenesis of the human pathogen Candida albicans, is a member of a conserved class of bHLH proteins regulating morphogenetic processes in fungi. EMBO J 16, 1982-1991.

Sudbery, P. E. (2001). The germ tubes of Candida albicans hyphae and pseudohyphae show different patterns of septin ring localization. Mol Microbiol 41, 19-31.

Sundstrom, P. (2002). Adhesion in Candida spp. Cell Microbiol 4, 461-469.

Sung, P., Prakash, S. \& Prakash, L. (1988). The RAD6 protein of Saccharomyces cerevisiae polyubiquitinates histones, and its acidic domain mediates this activity. Genes Dev 2, 1476-1485.

Swain, E., Baudry, K., Stukey, J., McDonough, V., Germann, M. \& Nickels, J. T., Jr (2002). Sterol-dependent regulation of sphingolipid metabolism in Saccharomyces cerevisiae. J Biol Chem 277, 26177-26184. 
Takahashi, M., Banno, Y. \& Nozawa, Y. (1991). Secreted Candida albicans phospholipases: purification and characterization of two forms of lysophospholipase-transacylase. J Med Vet Mycol 29, 193-204.

Tzermia, M., Horaitis, O. \& Alexandraki, D. (1994). The complete sequencing of a $24.6 \mathrm{~kb}$ segment of yeast chromosome XI identified the known loci URA1, SAC1 and TRP3, and revealed 6 new open reading frames including homologues to the threonine dehydratases, membrane transporters, hydantoinases and the phospholipase A2activating protein. Yeast 10, 663-679.
Wolfe, D., Hester, P. \& Keil, R. L. (1998). Volatile anesthetic additivity and specificity in Saccharomyces cerevisiae: implications for yeast as a model system to study mechanisms of anesthetic action. Anesthesiology 89, 174-181.

Yang, H., Bard, M., Bruner, D. A., Gleeson, A., Deckelbaum, R. J., Aljinovic, G., Pohl, T. M., Rothstein, R. \& Sturley, S. L. (1996). Sterol esterification in yeast: a two-gene process. Science 272, 1353-1356.

Edited by: J. Pla 